\title{
The excavation at Limyra/Lycia 2016: preliminary report
}

Martin Seyer, Alexandra Dolea, Kathrin Kugler, Helmut Brückner and Friederike Stock

\section{(2) OpenEdition \\ 1 Journals}

\section{Electronic version}

URL: http://journals.openedition.org/anatoliaantiqua/458

DOI: 10.4000/anatoliaantiqua.458

\section{Publisher}

IFEA

\section{Printed version}

Date of publication: 1 May 2017

Number of pages: $143-160$

ISBN: 978-2-36245-066-2

ISSN: 1018-1946

\section{Electronic reference}

Martin Seyer, Alexandra Dolea, Kathrin Kugler, Helmut Brückner and Friederike Stock, « The excavation at Limyra/Lycia 2016: preliminary report », Anatolia Antiqua [Online], XXV | 2017, Online since 01 May 2019, connection on 19 December 2020. URL : http://journals.openedition.org/anatoliaantiqua/458 ; DOI : https://doi.org/10.4000/anatoliaantiqua.458 


\section{ANATOLIA ANTIQUA ESKI ANADOLU}

\section{XXV}

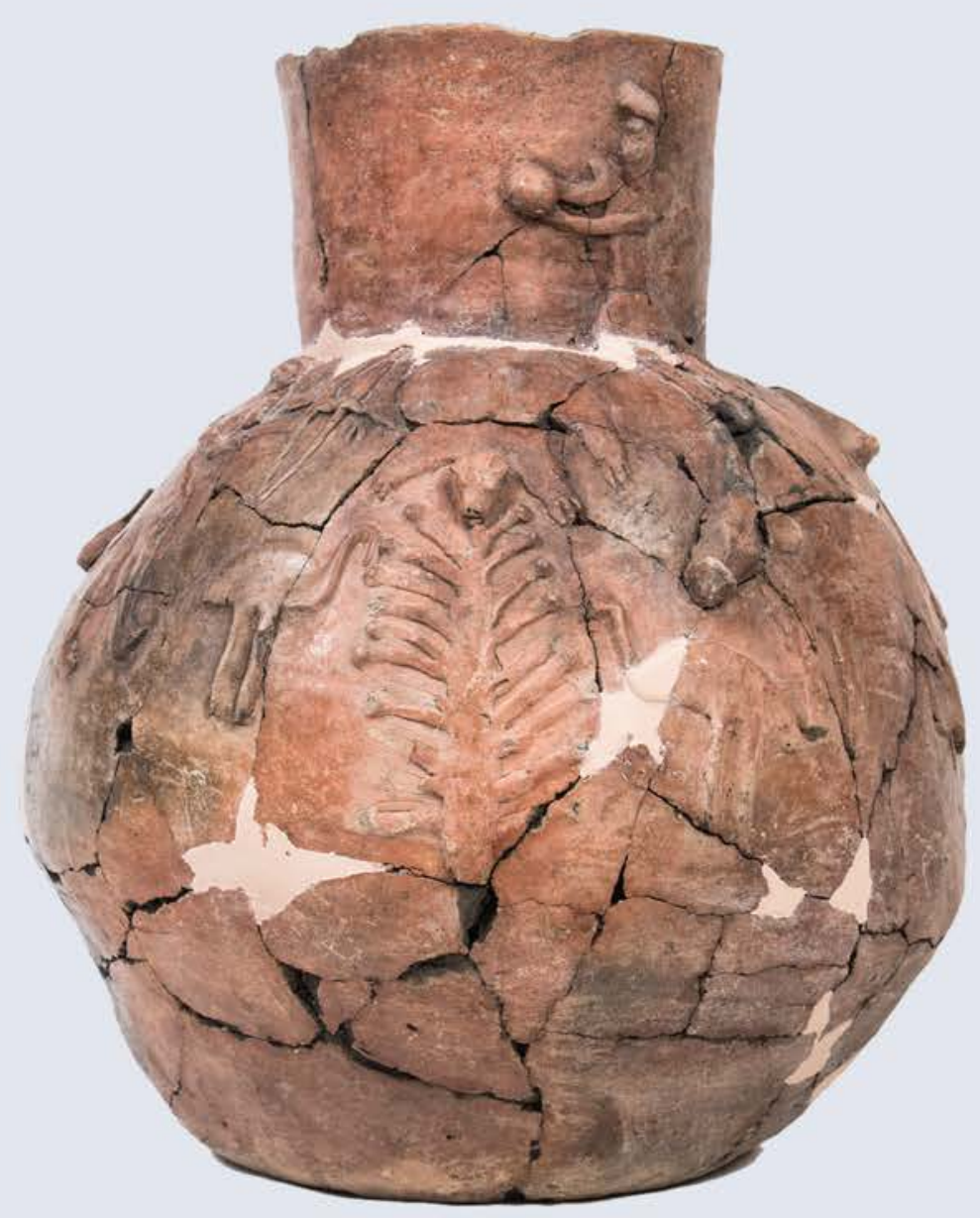

INSTITUT FRANÇAIS D'ETUDES ANATOLIENNES GEORGES-DUMEZIL

CNRS USR 3131

DE BOCCARD 


\section{TABLE DES MATIERES}

N. Pınar ÖZGÜNER et Geoffrey D. SUMMERS

The Çevre Kale Fortress and the outer enclosure on the Karacadağ at Yaraşl1

Abuzer KIZIL et Asil YAMAN

A group of transport amphorae from the territorium of Ceramus: Typological observations

Tülin TAN

The hellenistic tumulus of Eşenköy in NW Turkey

Emre TAŞTEMÜR

Glass pendants in Tekirdağ and Edirne Museums

Liviu Mihail IANCU

Self-mutilation, multiculturalism and hybridity. Herodotos on the Karians in Egypt (Hdt. 2.61.2) .....

\section{CHRONIQUES DES TRAVAUX ARCHEOLOGIQUES EN TURQUIE 2016}

Erhan BIÇAKÇI, Martin GODON et Ali Metin BÜYÜKKARAKAYA, Korhan ERTURAÇ, Catherine KUZUCUOĞLU, Yasin Gökhan ÇAKAN, Alice VINET

Les fouilles de Tepecik-Çiftlik et les activités du programme Melendiz préhistorique, campagne 2016

Çiğdem MANER

Preliminary report on the forth season of the Konya-Ereğli Survey (KEYAR) 2016

Sami PATACI et Ergün LAFLI

Field surveys in Ardahan in 2016

Erkan KONYAR, Bülent GENÇ, Can AVCI et Armağan TAN

The Van Tušpa Excavations 2015-2016

Martin SEYER, Alexandra DOLEA, Kathrin KUGLER, Helmut BRÜCKNER et Friederike STOCK The excavation at Limyra/Lycia 2016: Preliminary report

Abuzer KIZIL, Koray KONUK, Sönmez ALEMDAR, Laurent CAPDETREY, Raymond DESCAT, Didier LAROCHE, Enora LE QUERE, Francis PROST et Baptiste VERGNAUD

Eurômos : rapport préliminaire sur les travaux réalisés en 2016

O. HENRY et D. LÖWENBORG, Fr. MARCHAND-BEAULIEU, G. TUCKER, A. FREJMAN,

A. LAMESA, Chr. BOST, B. VERGNAUD, I. STOJANOVITC, N. CARLESS-UNWINN,

N. SCHIBILLE, Ö.D. ÇAKMAKLI, E. ANDERSSON

Labraunda 2016 


\section{CHRONIQUES DES TRAVAUX ARCHEOLOGIQUES EN TURQUIE \\ 2016}




\section{Martin SEYER, Alexandra DOLEA, Kathrin KUGLER, Helmut BRÜCKNER and Friederike STOCK ${ }^{*}$}

\section{THE EXCAVATION AT LIMYRA/LYCIA 2016: PRELIMINARY REPORT}

The 2016 Campaign at Limyra commenced on August $8^{\text {th }} 2016$ with the permission granted by the Turkish Ministry of Culture and Tourism. Due to the early termination of the Austrian excavations by the Ministry of Foreign Affairs of the Republic of Turkey it had to be finished on August $31^{\text {st }}$. We would like to express our thanks to the state representative Çaylan Ulutaş of Antalya Museum.

\section{RESEARCH FOCUS "URBANISTIC STUDIES IN LIMYRA" (M. Seyer)}

With the approval of the scientific project "The Urbanistic Development of Limyra in the Hellenistic Period" for three years by the Austrian Science Fund (FWF) (P29027-G25), the research program on urbanism that had already been conducted for several years ${ }^{1}$ could be intensified in 2016. Particular focus should be given to the development of Limyra especially in the period under consideration, whereby the extent, the structures, and the urban image of the eastern Lycian city of Limyra from the time of Ptolemaic rule in the $3^{\text {rd }}$ century B.C. until the early Imperial period will be studied in their historical context.

The extent and the character of Zẽmuri/Limyra (Fig. 1), after its expansion into a seat of royal power by the dynast Pericles at the beginning of the $4^{\text {th }}$ century B.C., have been adequately studied through many years of excavation. The scant knowl- edge of the urban development of Limyra during the Hellenistic period is, however, symptomatic for the archaeological investigation of Lycia, since the situation is similar in the other large cities of this region. The importance of Limyra in early Hellenism is testified mainly by the impressive remains of the Ptolemaion of the first half of the $3^{\text {rd }}$ century B.C. ${ }^{2}$, by several fragments of a monumental building of the Ionic order reused as spolia in the Late Antique/early Byzantine city wall of the East $\mathrm{City}^{3}$, as well as by several blocks decorated with depictions of $\mathrm{bu}$ crania, some of which also were reused in the same city wall (Fig. 2) ${ }^{4}$. A huge foundation which was found in the area of the Byzantine West Gate in 2012 and which has been assigned experimentally to a peripteros has to be mentioned in this context either, since due to the pottery discovered it should be dated in the early Hellenistic period ${ }^{5}$. Together with the impressive archaeological finds, the rich epigraphic evidence of this epoch not only allows conclusions regarding the importance of the city, but also the existence of various buildings not localised so far ${ }^{6}$.

Therefore, it is remarkable that during numerous excavations at various places in Limyra, only very scant Hellenistic phases have been found. This is striking mainly for the excavations in the West City close to the classical city wall ${ }^{7}$ and in the residential area at the lower slope of the acropolis hill ${ }^{8}$, as especially in these areas Hellenistic strata and building phases were to be expected. At the moment the im-

*) M. Seyer and A. Dolea, Austrian Archaeological Institute, Vienna; K. Kugler, Ludwig Maximilian University of Munich; H. Brückner and F. Stock, Institute of Geography, University of Cologne.

1) Seyer $2013: 59-63$; Seyer, in press. For the results of the field campaigns from 2011-2015 at Limyra see the regular preliminary reports in "Kazı Sonuçları Toplantıs1" as well as in "News of Archaeology from Anatolia's Mediterranean Areas".

2) Cf. recently Stanzl 2012, 2016.

3) Cavalier 2012.

4) Dinstl 1993. For a short list of further architectural evidence of the early Hellenistic period: Marksteiner 2012: 202.

5) Seyer and Schuh 2013: 407-408; 2013a: 87.

6) Wörrle 1977, 2010, 2011, 2012, 2015.

7) Konecny and Marksteiner $2007: 26$.

8) Seyer 1991/92, 1993, 1997. 


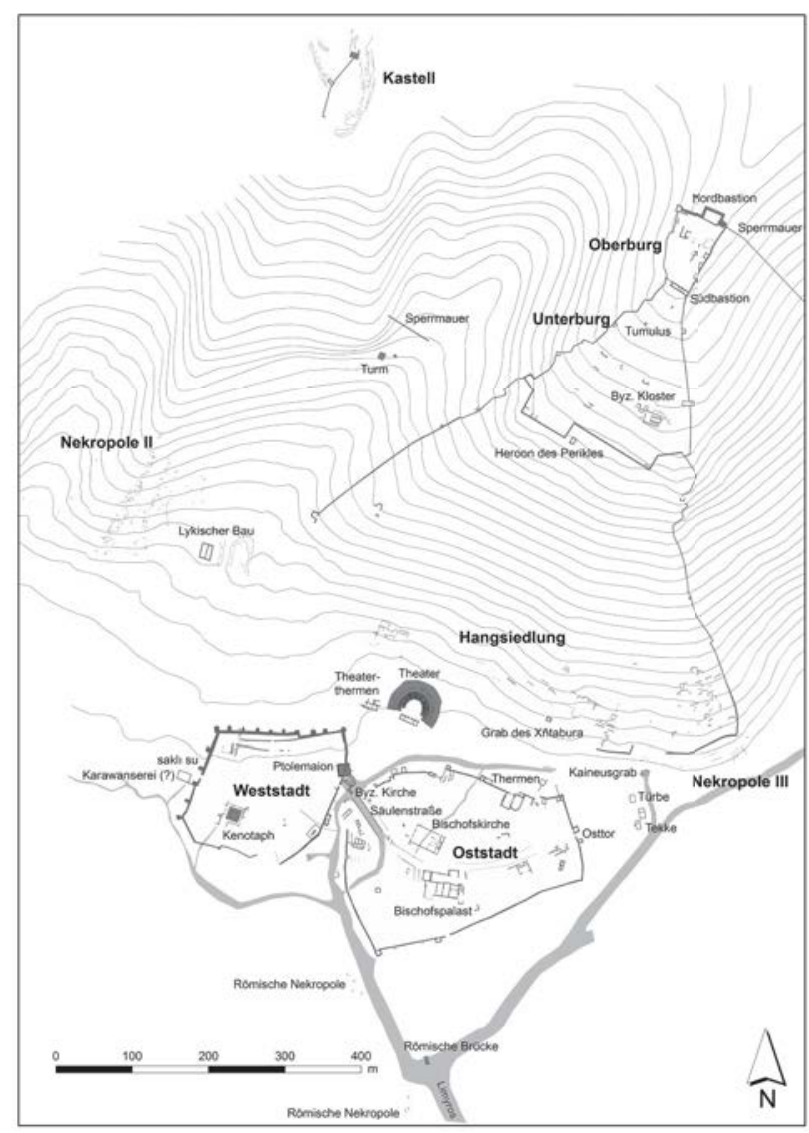

Fig. 1 : Limyra, city plan (Plan: C. Kurtze).

portance of Limyra in the Hellenistic period is testified mainly by the above mentioned monuments. Our knowledge of the urban development is still very sparse. The restoration and partial reconstruction of the damaged classical fortifications ${ }^{9}$ could be viewed as the only testimony of the Hellenistic period in Limyra that could be understood as an urbanistic measure in the broadest sense.

During excavations in 2012, close to the Byzantine West Gate of Limyra (Fig. 3), however, a section of the Hellenistic fortification wall was found (Fig. 4). This wall indicates that Limyra was enlarged for approx. $80 \mathrm{~m}$ to the South in the Early Hellenistic period, as according to the pottery found in the foundations the wall can be dated in this epoch ${ }^{10}$. The fortification wall has been excavated only for
$20 \mathrm{~m}$ so far, but together with the results of the geophysical survey conducted in 2013 and 2014 (Fig. 5) ${ }^{11}$ it forms one of the basic elements which provide new ideas about the general lay out and the urbanistic development of the city of Limyra. The realisation that the area of Limyra was enlarged in the early Hellenistic period, most probably built to modern standards, constitutes a first important step within the investigation of the Hellenistic city.

As the next step, based on the (preparatory) research during the last years, a scientific project concerning the urbanistic development of Limyra in the Hellenistic period was worked out. With a term of three years this project will attempt to answer questions concerning the extension and the borders of the city in the time under consideration, a more precise dating of the urban expansion, a possible uniform orientation and a street grid of the developed areas, architectural constituents of Limyra (type and chronology of the buildings), a classification of the numerous fragments of sacred buildings, and a typological chronology of the findings, just to mention a few of the aims.

In order to achieve the ambitious goals for the 2016 season several excavations ${ }^{12}$, geoarchaeological and geophysical surveys, architectural and epigraphic studies, an intraurban survey, and a project to study the numerous architectural blocks used as spolia in the Late Antique city-walls were planned. However, just a small part of these research projects could be carried out. The geoarchaeological survey could be conducted as planned, archaeological excavation could take place for three weeks in one of the planned areas, and the study of the Classic and Hellenistic pottery could be started. Due to the early and unexpected termination of the excavation by the Turkish Ministry of Foreign Affairs the remaining investigations could not take place and had to be postponed.

\section{THE PRELIMINARY RESULTS OF 2016 LIMYRA EXCAVATION CAMPAIGN} (A. Dolea)

The excavation in the West city of Limyra started on the $8^{\text {th }}$ of August 2016 with the purpose of

9) Marksteiner 1997: 69-73, 199-201.

10) As first studies show, the material contains mainly fragments of the so called "Streifen- und Wellenbandkeramik" and blackglazed-ware, both of the Classical period: cf. the contribution of K. Kugler below and Kugler, in press.

11) Seyer, in press.

12) The first sector was considered in the area close to the Byzantine West Gate, where the results of the geophysical survey show a structure which we might interpret as a city gate (Seyer, in press). Another excavation was planned in the area north to the Cenotaph of C. Caesar (see the contribution of A. Dolea below). Finally, a small sondage was scheduled close to the SE corner of the East City where the geophysical results suggest a part of a city wall which seems to mark the eastern limit of the Hellenistic city. 


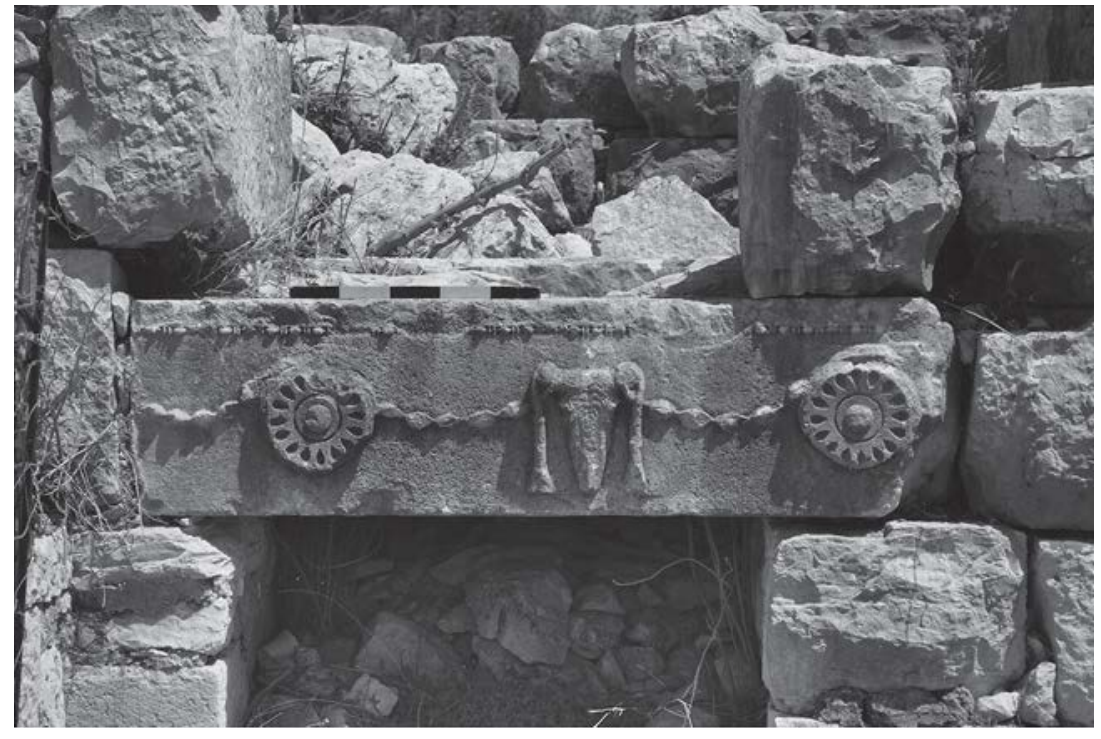

Fig. 2 : Limyra, block with the depiction of a bukranion (Photo: R. Hügli).

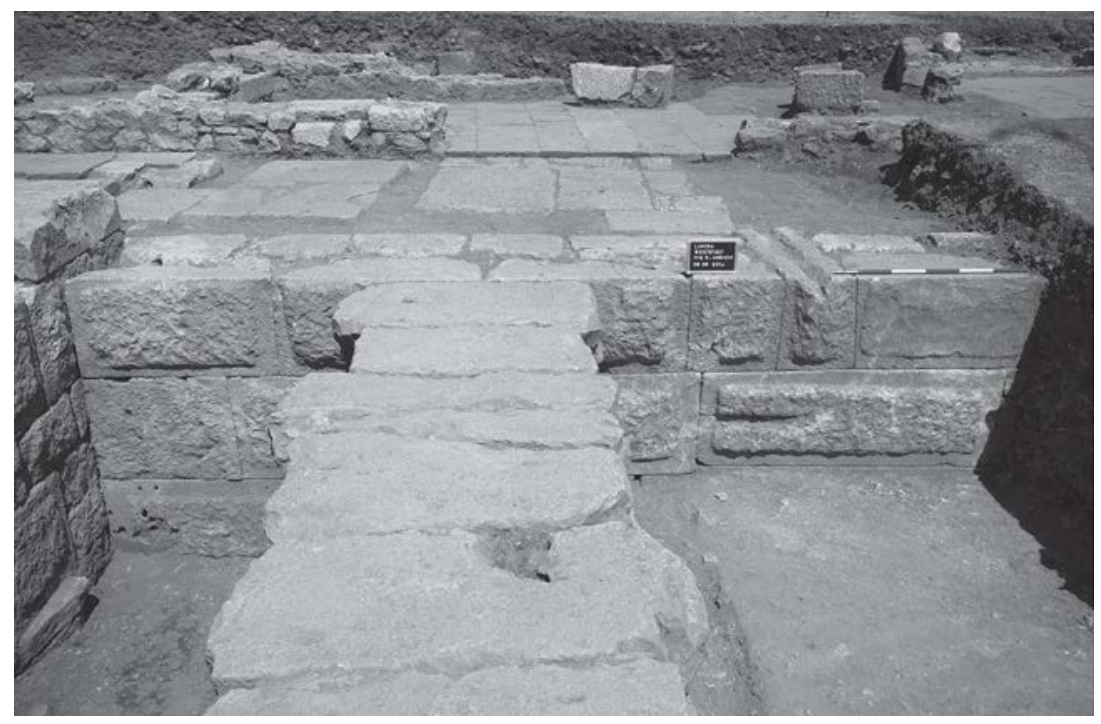

Fig. 4 : Limyra, section of the Hellenistic city wall (Photo: R. Hügli).

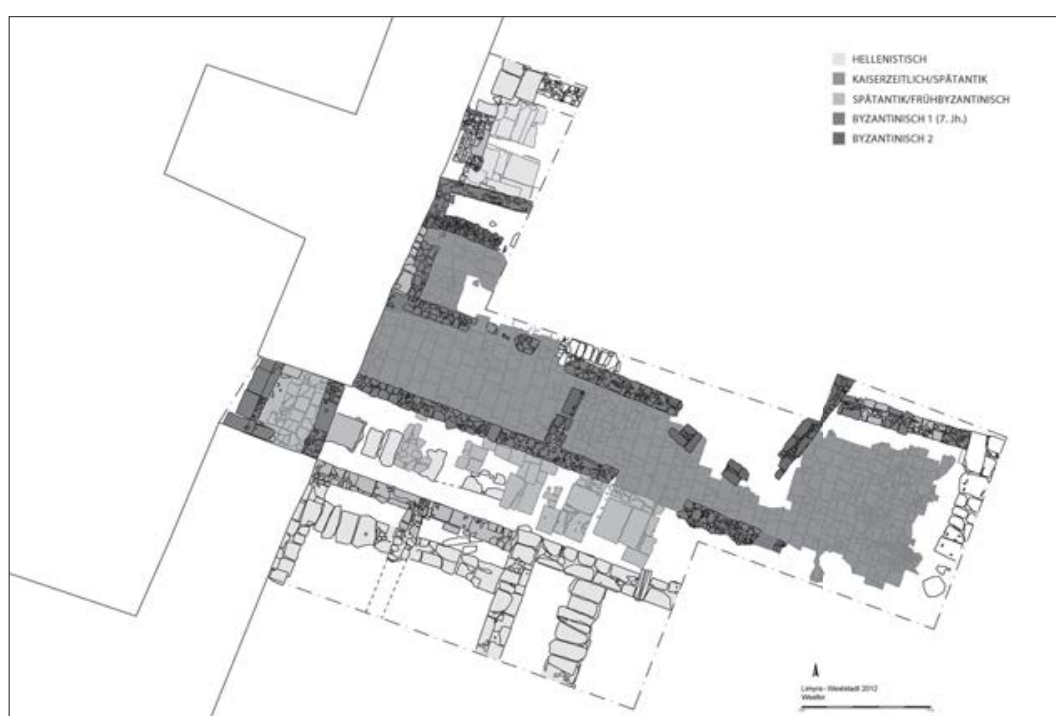

Fig. 3 : Limyra, plan of the excavation at the West Gate (Plan: U. Schuh).

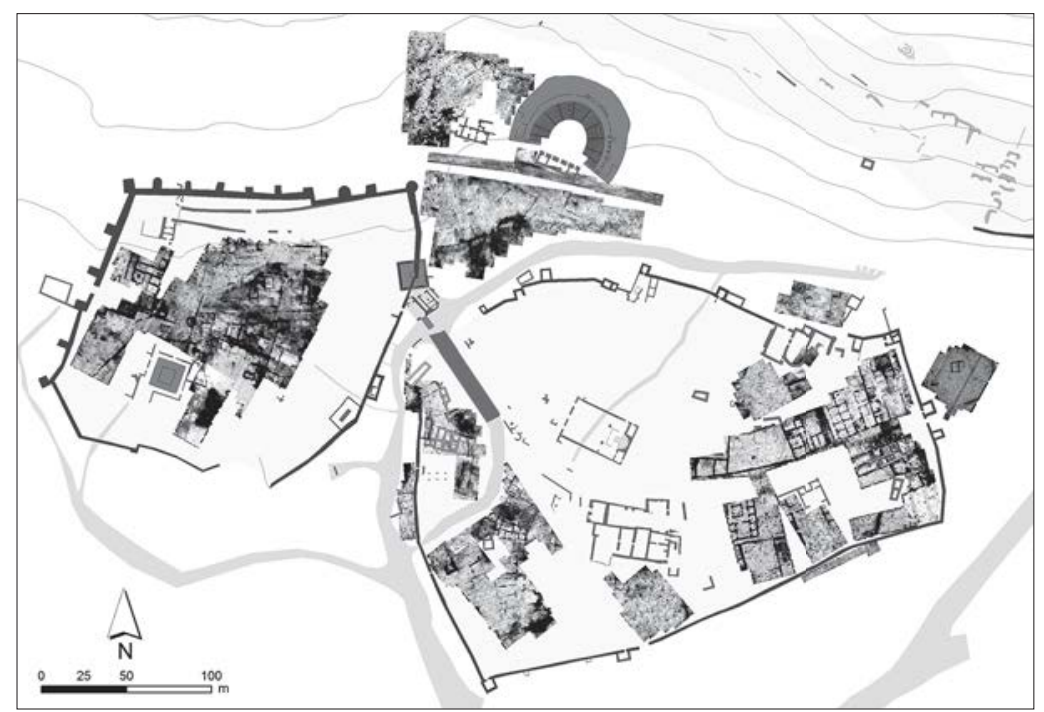

Fig. 5 : Limyra, plan of the Lower City with the results of the Georadar (Plan: C. Kurtze. Measurements: S.S. Seren). 
verifying the results of the Ground Penetrating Radar (GPR) undertaken in 2013 in the area to the north of the Cenotaph of Gaius Caesar and to the east of the West gate of the Late Antique city wall ${ }^{13}$. This area was interpreted as a central point (maybe a plaza) with a circular structure in the middle ${ }^{14}$. Also, a street was identified as starting from the previously mentioned structure and running to the east. The orientation of the assumed square and of the street suggests that the regular orientation of the city plan, which was established in the Hellenistic period, was abandoned due to reasons which are as yet unknown. As this area therefore plays a key role in the understanding of the urbanistic development of Limyra in the late Hellenistic/Early Imperial period, an excavation should help to clarify the approximate date and perhaps the reason of this change. The position of the trenches was chosen in order to capture as much information as possible concerning the street, the square and the round building at the immediate junction of these three structures (Fig. 6).

The surface of the sector was split in six trenches (SO 01 - SO 06) measuring 4 x $4 \mathrm{~m}$ with $1 \mathrm{~m}$ distance in between. Excavation began simultaneously in all of the six trenches, in order to obtain an immediate overview of the entire situation (Fig. 7-8)

As mentioned above, the excavation was limited to three weeks; it consisted in proceeding with the work on the field and in the depot. In all the trenches the uppermost layers were interpreted as recent humus depositions and modern interventions, such as foundations for the greenhouses which were built on the site in the 1970s (Fig. 9). In SO 01 and 02 a plastic water pipe and electric cables had caused severe damage, especially to an ancient circular construction mentioned above. The pipes and wires were removed. In the other trenches (SO 03 - SO 06), modern interventions (i.e. the construction remains of greenhouses and other agricultural features) could be observed as well. Below them, layers with mixed material and ancient layers and structures were reached.

\section{Sondage 01/16 (SO 01)}

SO 01 contains the NE quarter of the round structure which is made of large stones at the exterior and smaller stones at the interior. All of them appear rather rough and they are joined with mud mortar mixed with small stones. The northern façade has three to five rows of large stones, the upper three rows being more carefully arranged, the lower rows protruding beyond the upper arrangement lines. It is very probable that the upper rows were the ones exposed, while the lower ones are a part of the substructure. To the east, the structure changes its composition as visible at the exterior, by displaying one or two rows of large stones lying on top of a filling layer composed of soil mixed with very small stones and ceramic construction material fragments.

It seems that this structure functioned in a late phase of the West City's chronological framework, not only due to the type of construction, but also due to the fact that its installation is built (at least partly) on top of a stone slab pavement (probably a street) and also dismantles a part of a wall. This dismantled wall is part of a construction which continues to the east and seems to be built before the stone plate pavement found in SO 02 - SO 05, but after the stone pavement from SO 01.

The stones of the pavement uncovered in the NW part of SO 01 seem to be used more intensively and are approximately $0.30 \mathrm{~m}$ deeper than the one uncovered in SO 02. The only analogy we could provide concerning its orientation and composition is the Imperial/Late Roman period street that starts from the West Gate to the east ${ }^{15}$. As mentioned above, this pavement terminates in an irregular form to the east and it seems that it was disturbed by the installation of some wall structures (Fig. 10-11).

\section{Sondage 02/16 (SO 02)}

To the south of SO 01 the documentation of the round structure continued. Its exterior diameter is ca $7 \mathrm{~m}$; the interior diameter $c a 3.30-3.50 \mathrm{~m}$, and the walls' thickness varies between $1.50-1.80 \mathrm{~m}$. The construction was severely damaged by modern interventions, but also by a pit documented in the S$\mathrm{E}$ area of the trench. The pit affected the circular construction itself, but also partly dismantled the stone pavement situated in the SE corner of the trench.

In an earlier phase, the round structure has three to five rows of stones visible on the outer façade. The later intervention/reparation has one row of stones on top of a filling layer composed of earth mixed with small size stones and fragmentary ceramic construction material. These details suggest that the round structure was still in use until a later date

13) We express our gratitude to the following collaborators: S. Anton, J. Hangartner, K. Kainz,H. Lotz, B. Orakçılar.

14) Seyer 2014 : 73-75; Seyer, in press.

15) Seyer and Schuh 2013a: 85-87. 


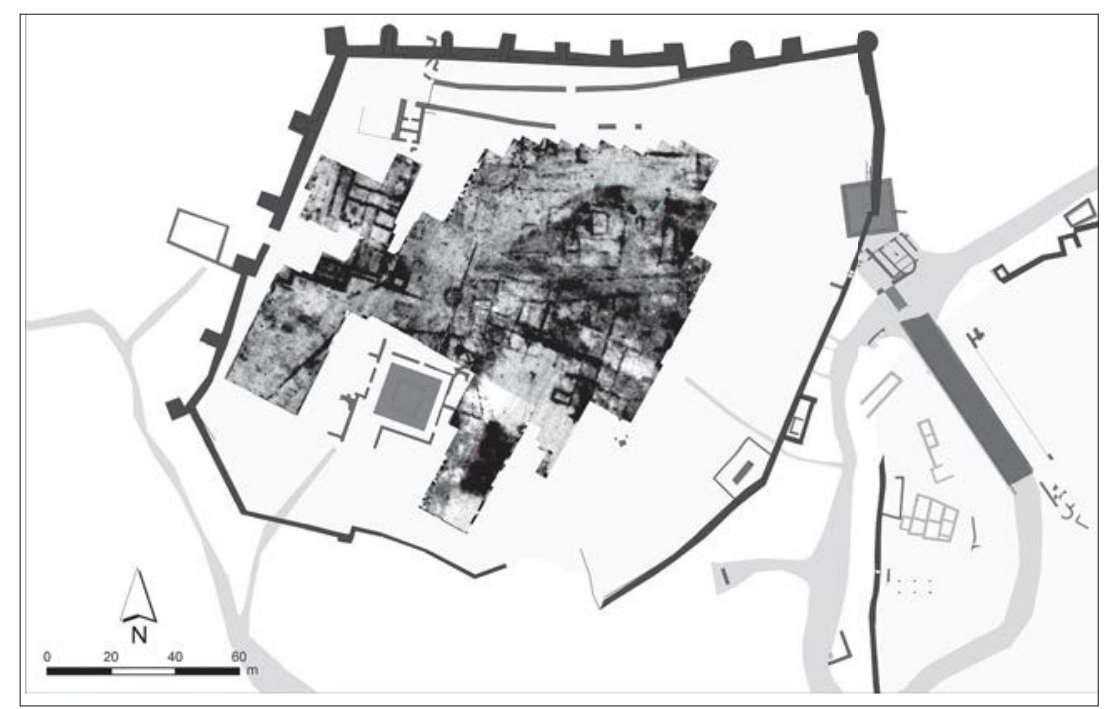

Fig. 6 : West city of Limyra, plan and geophysical scan with the localisation of the LiPW16 excavation (Plan: C. Kurtze).

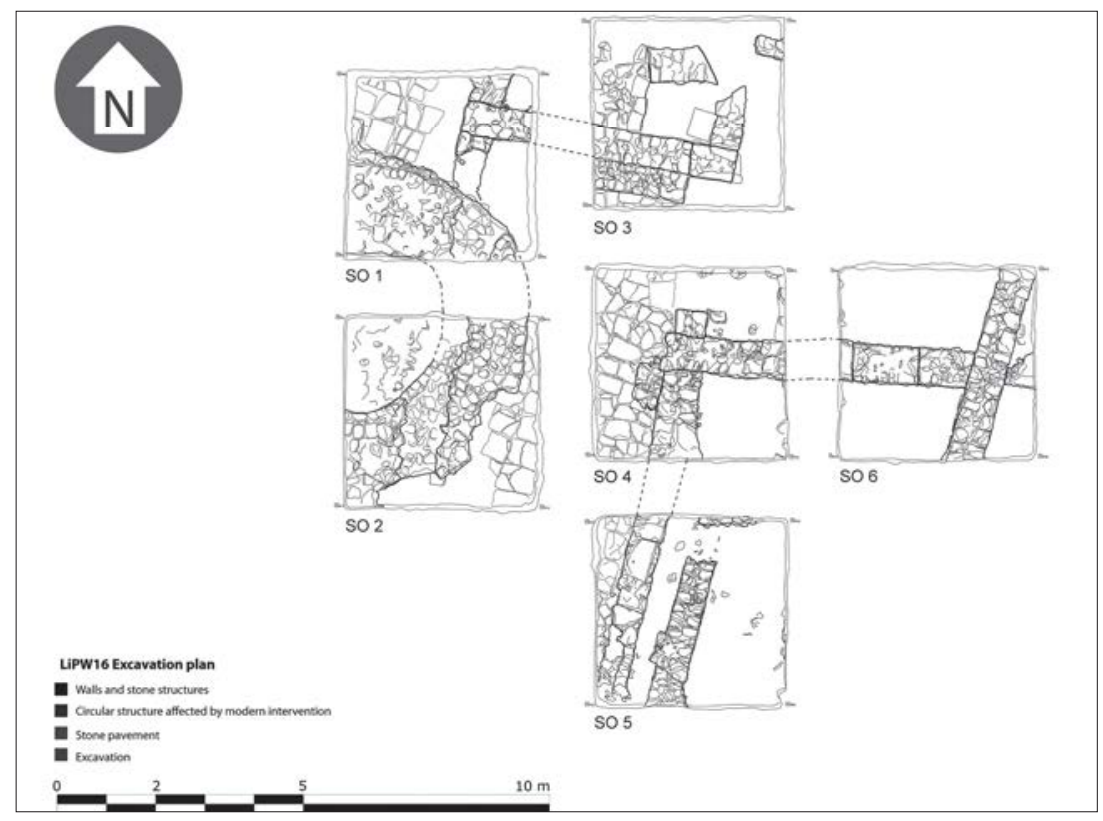

Fig. 8 : LiPW16 excavation plan (Plan: Lynn Karkouki, ÖAI).

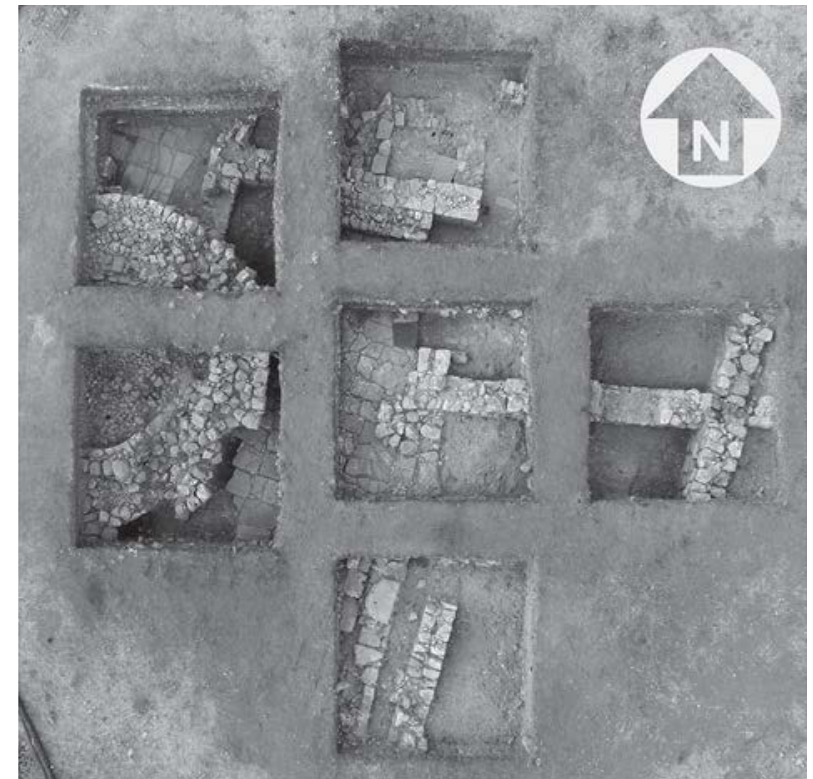

Fig. 7 : Drone photography of LiPW16 at the end of 2016 excavation season (Photo: C. Kurtze).

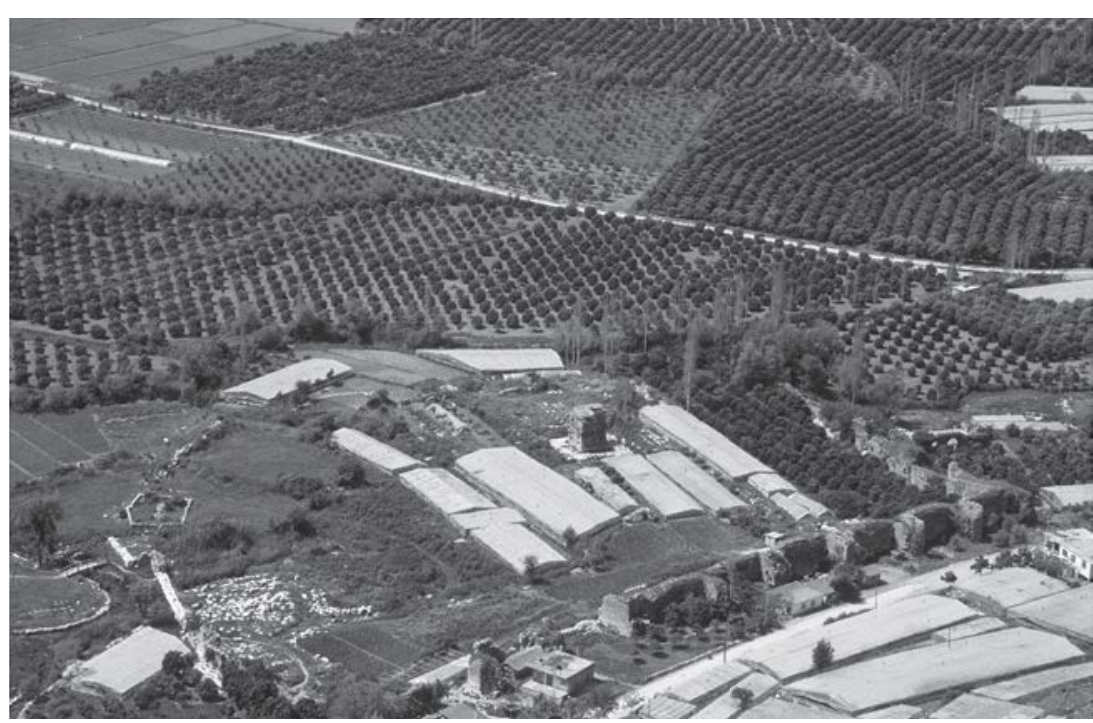

Fig. 9 : Greenhouses installed north of the Cenotaph of C. Caesar in 1980s. View from NE (Photo: ÖAI). 
(Late Antiquity/Early Byzantine), especially due to the latest intervention that is of poorer quality than the main construction. This secondary intervention was identified, for now, mostly to the east and south-east exterior line of this structure.

At the current stage of research, it is not possible to recognize a function for the round structure, since its interior filling(s) could not be excavated during the 2016 season. The inner line of the circular structure is worked very carefully, made of rectangular stones joined with hydraulic lime mortar. This detail indicates a water-related use. Still, the fact that the geophysical scans indicate a depth of the structure of approximately $1.80-2 \mathrm{~m}$, the possibility of a storage construction (i.e. for cereals) ${ }^{16}$, while the use of hydraulic lime mortar only on the interior line of the structure can be explained as a measure against dampness (Fig. 12).

The stone pavement uncovered in the east half of the trench is either part of a street (which comes from south, most probably from the Cenotaph of C. Caesar area, but ends to the north in a double wall from SO 3), or a part of a larger pavement of a plaza/square, which was affected by later interventions, such as the circular structure and the above mentioned pit. The pavement's orientation is SSE - NNW and it was identified in SO 02 - SO 05, starting under the round structure and stopping in wall structures towards east and north (Fig. 8).

\section{Sondage 03/16 (SO 03)}

The situation in SO 03 raises many questions of interpretation concerning the urbanistic development in the West City of Limyra. Along with a cumulation of structures which appear to be built in different periods, the end of the stone pavement traced in SO 02 - SO 05 was identified and it stops in a double wall (see above).

In this area the excavation was discontinued after revealing some earlier wall structures which seem to have been dismantled and levelled, then covered with a mud floor. This technique was frequently employed in the Late Antique period, especially for changing the organization of a building, the functionality of an area etc. The contour of a pit which seems to disturb at least two wall structures was also identified (Fig. 13).

\section{Sondage 04/16 (SO 04)}

This trench provides a better understanding of the architectural and urbanistic features and reveals more details concerning the chronological relation between the above-mentioned structures. The uncovered pavement reaches the western wall of a building, the NW side of which was partly revealed. This indicates that the pavement is contemporaneous or later than the construction of the walls. Also, the walls continue to south and east forming, most probably, a room; however its south limit was not reached this year. On top of these structures a layer of collapsed roof tiles covering especially the inner area between the walls was found (Fig. 14).

\section{Sondage 05/16 (SO 05)}

In the NW corner of this trench the continuation of the pavement revealed in SO $02-\mathrm{SO} 04$ is visible. As in $\mathrm{SO} 04$, it is limited by a wall that runs NNE - SSW. Probably the wall marks the continuation of the archaeological features uncovered in SO 04. At its uppermost preserved layer a re-used threshold with heavy traces of usage was identified.

Immediately to the east of the above-mentioned wall, there is a parallel wall without any connection towards its north end; it extends into the south profile. Although a relative chronology could not yet be established, it seems this wall is related to a later phase of the city, when the above-mentioned structures were already out of use and covered with a mud floor/walking horizon. On top of the mud floors a layer of collapsed roof tiles was documented in the east half of the trench. As in the case of SO 04, the excavation and documentation of this trench stopped also on a mud floor layer (Fig. 15).

\section{Sondage 06/16 (SO 06)}

The wall structures uncovered inside this trench indicate a rather Late Antique construction and function due to the building technique and the presence of a large, reused block. This block reaches into the west profile and marks probably an installation of an access way towards the east (Fig. 17).

Large quantities of Late Antique pottery sherds and small finds were collected from mud floors and filling layers which were documented in this area.

16) Similar, but smaller, structures were uncovered at Histria (RO), where they were initially considered as being (bread) ovens, and Tropaeum Traiani (RO), where the most probable functional interpretation was given as "small depots for cereals", Barnea, 1979: 83, n. 5; Panaite et al. 2009 (2010): 13; Gămureac 2010: 204-205. 


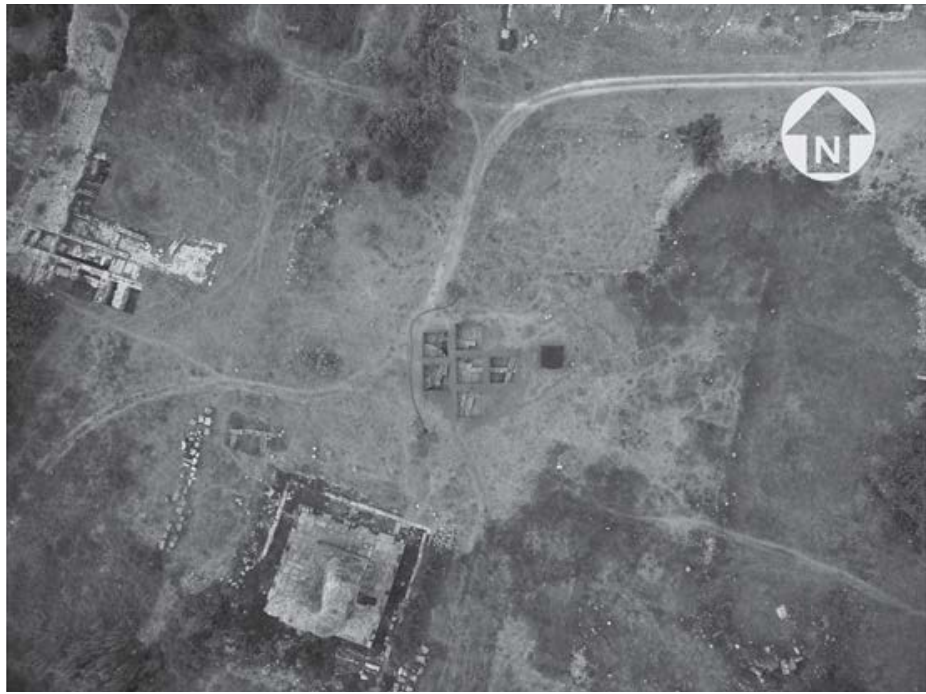

Fig. 10 : Drone photography of the West Gate excavation, LiPW16 and the Cenotaph (Photo: C. Kurtze).

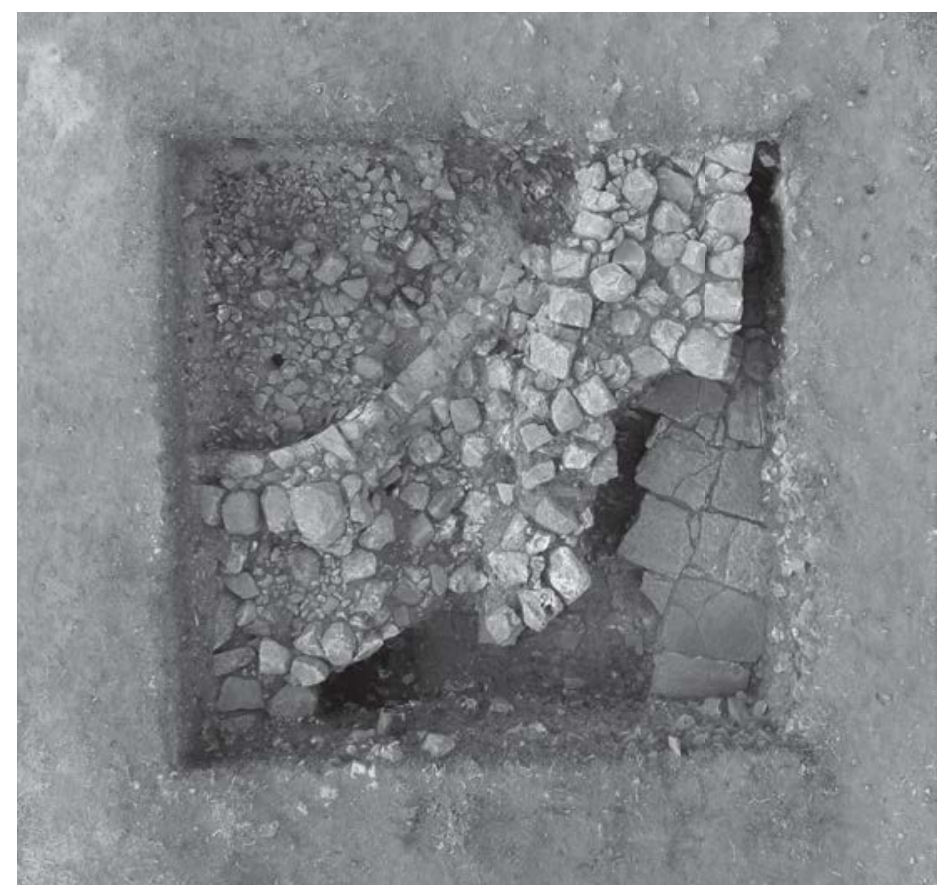

Fig. 12 : SO 02 at the end of the excavation campaign (Photo: C. Kurtze).

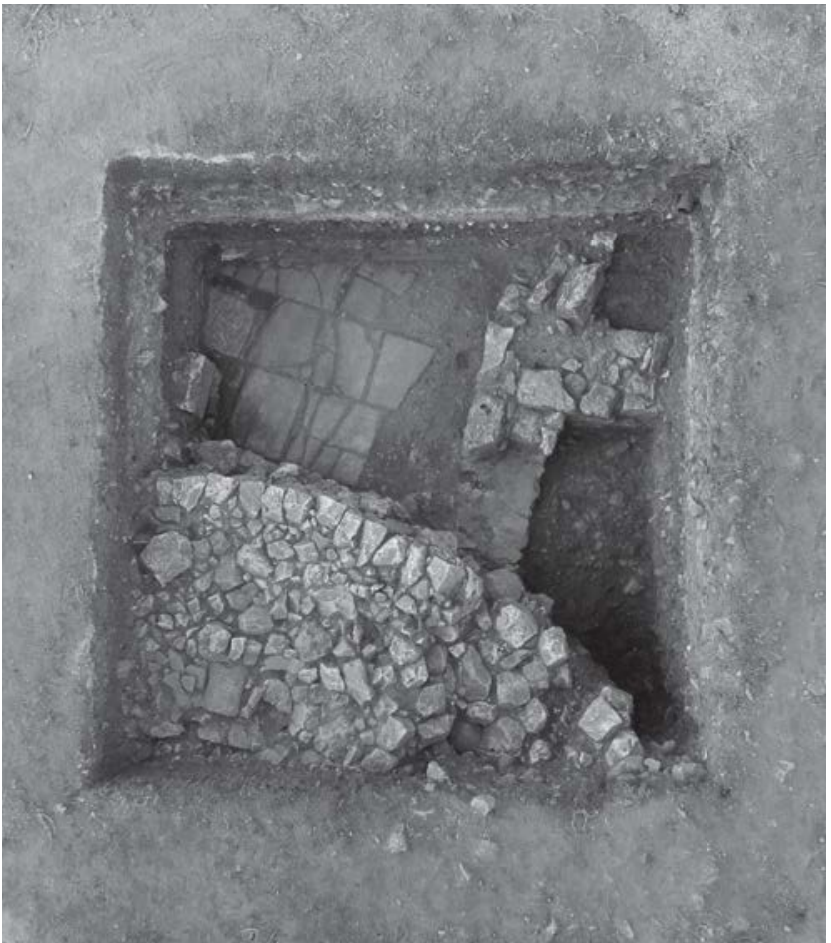

Fig. 11 : SO 01 at the end of the excavation campaign (Photo: C. Kurtze).

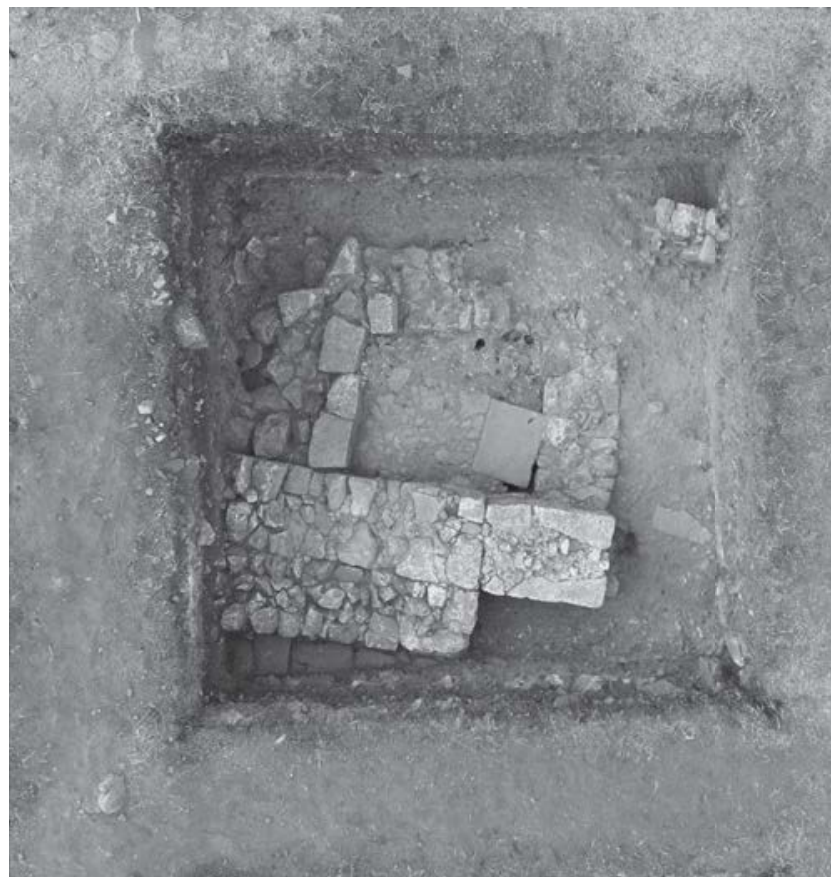

Fig. 13 : SO 03 at the end of the excavation campaign (Photo: C. Kurtze). 


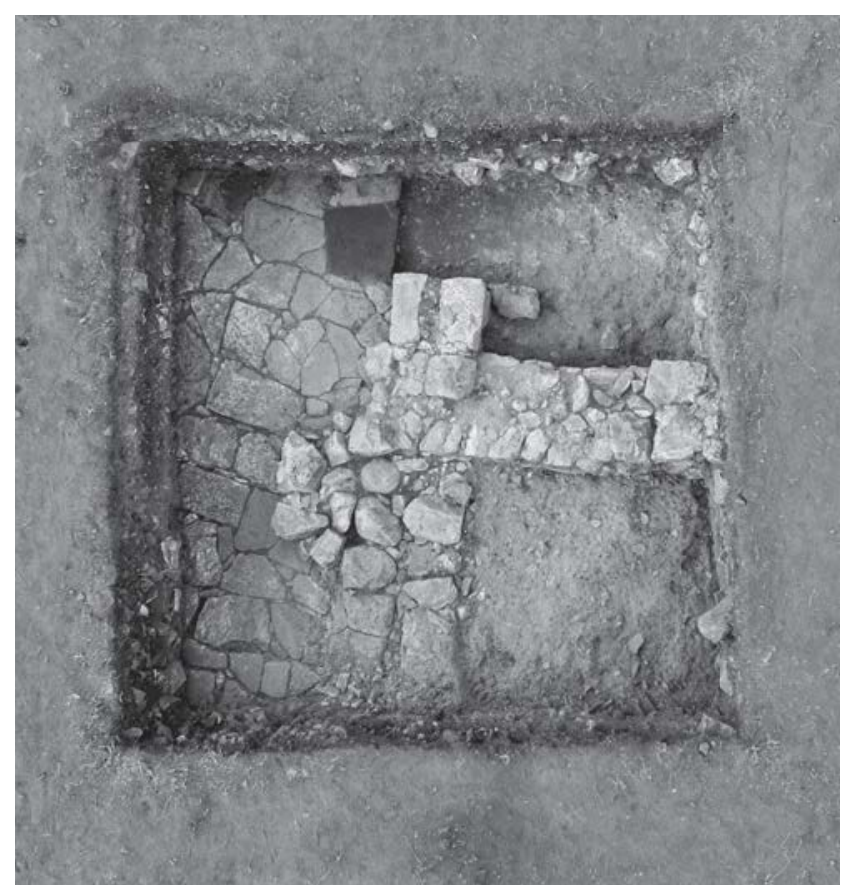

Fig. 14 : SO 04 at the end of the excavation campaign (Photo: C. Kurtze).

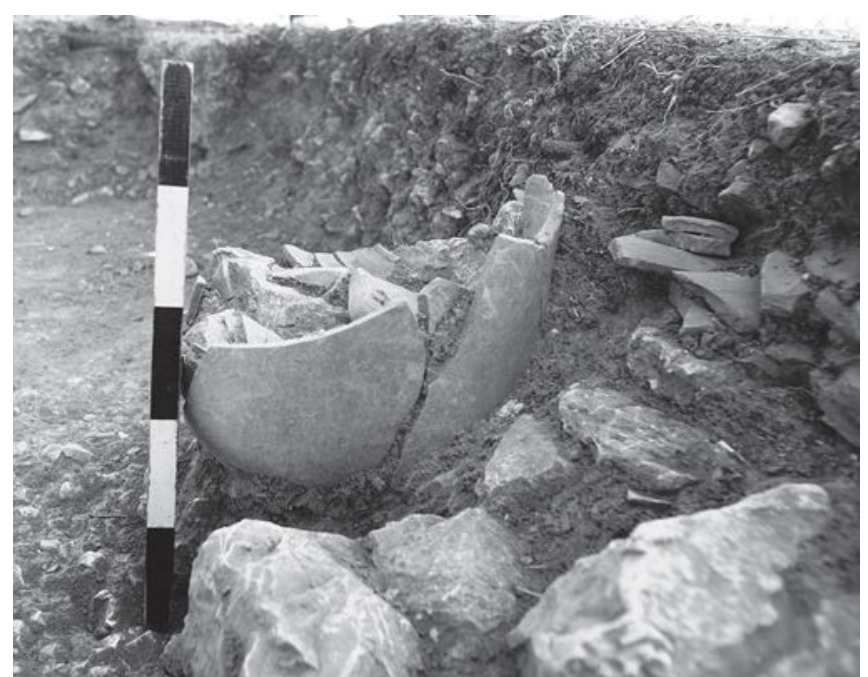

Fig. 16 : SO 05 - 2/3 of a Tunisian amphora of a Late Roman type fixed in a mud floor. View from W (Photo: A. Dolea).

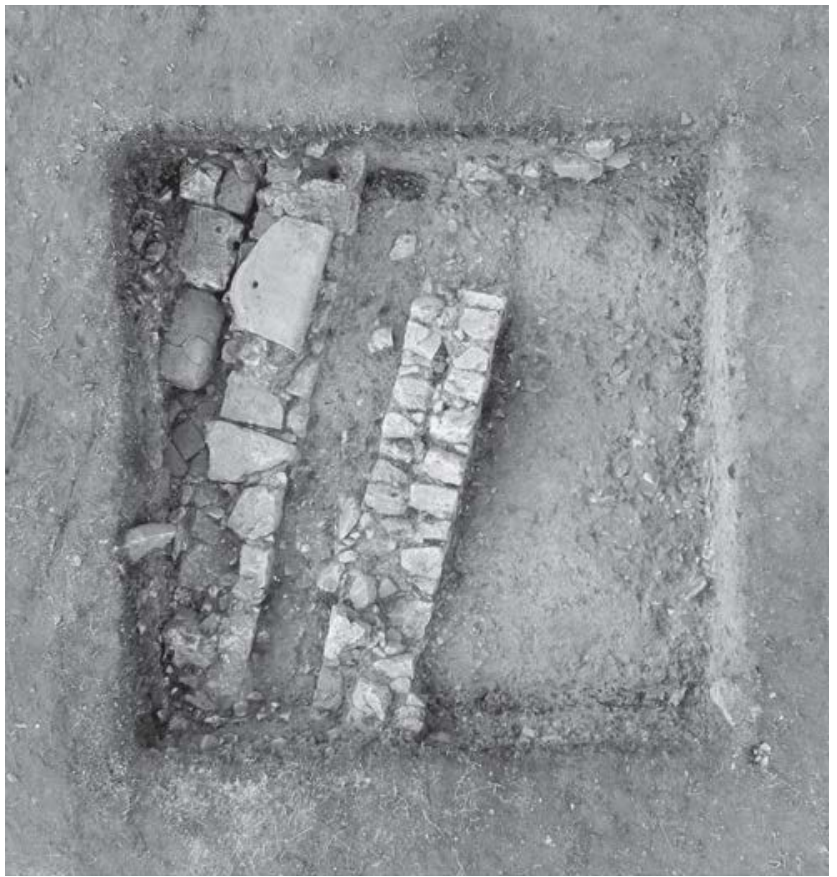

Fig. 15 : SO 05 at the end of the excavation campaign (Photo: C. Kurtze).

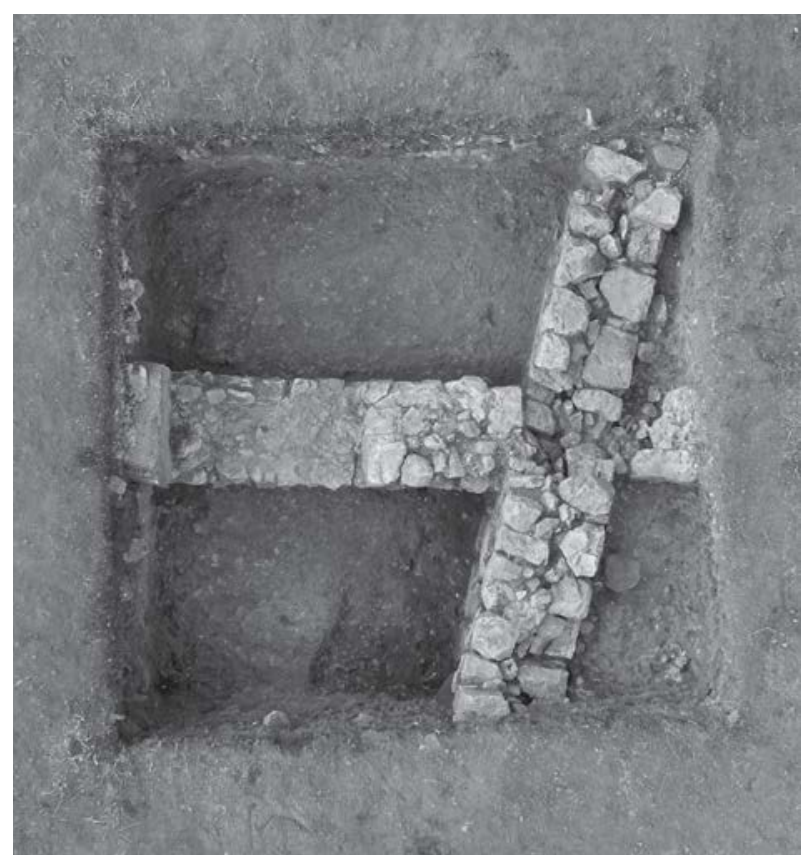

Fig. 17 : SO 06 at the end of the excavation campaign (Photo: C. Kurtze). 
Also, a collapsed roof was identified over almost the whole surface of the trench, indicating that the density of their spread is concentrated in between the walls.

\section{Chronology and small finds}

During this short campaign 255 bronze coins were found, a remarkable quantity compared with previous years. The great majority come from welldocumented contexts such as mud floors or fillings, especially from SO 05 and SO 06.

The coins were found in layers which indicate the final phases within the uncovered wall structures. A small part of the material could be primarily restored $^{17}$, but, due to the sudden end of the excavation season, it was not possible to complete their documentation. From a chronological point of view, the coin finds correlate to the rest of the finds, falling between the $5^{\text {th }}$ and the $7^{\text {th }} \mathrm{c}$. A.D. As every year the coins were brought to the Antalya Archaeological Museum where they will be studied by a numismatist.

The preliminary information indicates a Late Roman-Early Byzantine majority of finds. Based on the pottery, the latest ancient layers which were least affected by modern interventions could be dated in the $6^{\text {th }}$ c. A.D., while earlier layers and finds belong to the second half of the $5^{\text {th }}$ c. A.D. ${ }^{18}$. The oil lamps found during the excavation belong to different types, but the ones which are at least almost complete are wheel made and conform to the so-called Bailey lamp Q3339, which has been identified earlier in Limyra excavations, and also at other sites such as Xanthos and Amorium, and also further afield in Sicily, Ravenna, Alicante or Cyprus. The chronological frame for these finds is between the $6^{\text {th }}$ and $7^{\text {th }}$ c. A.D. ${ }^{19}$. Furthermore, the amphora fragments (especially some Pontic carrot shards) seem to provide interesting information that fits with similar finds from previous excavations at the East Gate of the East City and West Gate of the West City ${ }^{20}$.

Another noteworthy find is the lower part of a Tunisian amphora of Late Roman type which apparently was fixed in a mud floor. It was positioned on the south limit of SO 05. (Fig. 16) It is not clear if its upper part was removed during a post-antique phase, in order to be reused as a depository place or perhaps as a "trash can", or if it was affected by the agricultural interventions mentioned above. It contained many pottery shards which came from different ceramic vessels, also some bronze fragments that seem to have formed a small bowl. The possibility of a recycling of the amphora is very probable since the fragments found inside it were considerably larger than the average Late Antique amphorae rim diameters, so it is to be presumed that the top was removed prior to the vessel being used as such ${ }^{21}$.

\section{Ceramic building material}

During this campaign an extensive study on the ceramic construction material was initiated by A. Dolea. According to the methodology, the study begins with statistics on different types of the given material, which is divided not only by form and fabric, but also by traces of production in terms of the straightening technique of the upper surface.

This type of material has been the focus of attention by other specialists working in Limyra, such as P. Bes who had already made a sample selection from Late Roman contexts in $2014^{22}$. The previous and recent analyses will be assembled in order to create a more complete image.

The preliminary information from the ceramic building material gathered from SO 03 - SO 06 shows a very compact material from the typological point of view (a great majority of Laconian panand cover-tiles), but with differences concerning the fabric. This year, it was possible to identify eleven fabrics only from a part of the cover-tiles discovered in SO 06.

At present we can suppose that this ceramic construction material was used in the Late Antique period, most probably for roofing private buildings. The majority of Laconian-type roof tiles used and the variety of their fabrics indicate either a certain number of production centres in the region or a series of small reparations of the roof. A more extended hypothesis would be that the material was deposited from an earlier period in a particular place in the vicinity or maybe within Limyra. A storage containing ceramic building material purchased from

17) We would like to thank B. Alıc for the restoration of some of the coins in such a short time. studies.

18) We would like to express our gratitude to P. Bes for providing chronological and typological information through his pottery

19) Vroom 2004: 304-305, fig. 8; 2005: 250, fig. 2; Marksteiner, Lemaitre and Yener-Marksteiner 2007: 270, 273 , Plate 23 -D1.

20) Bes 2015: 79.

21) We would like to express our gratitude to P. Bes for this information.

22) Bes 2015: 80. 
different craftsmen would explain the variety of fabrics. Still, if the pieces were purchased for an actual use, the similarity of the types would have been the main interest of the buyer. In order to confirm these hypotheses, or provide new explanations, the study needs to be extended.

During the next season this research will continue, with gathering and documenting all the above-specified material. By correlating the archaeological layers and finds to the information gained through this research, new information concerning antique architecture, economy and production of Limyra and Lycia could be revealed. Another important aspect would be the comparative analyses between the fabrics selected from pottery (which is considered to be of regional production) and selected fabrics of the ceramic building material, in order to establish similarities and/or differences. Since such research has not been done in the Lycian area yet, this study represents pioneering work for this region.

\section{Conclusions}

Due to the unforeseen termination of the excavation, Hellenistic and Roman Imperial layers could not be reached. In any event, the excavation provided valuable information regarding Limyra in the Late Antique period.

It was possible to document at least two phases of construction for the circular structure and its stratigraphic relation with the surrounding features.

At this stage of research, it can be stated that the earliest structures identified seem to show some Roman features (opus caementicium), but these are few and only partly preserved, reused in later constructions. It seems that the stone slab pavement running NNE - SSW was installed after the construction of the wall structures revealed in the trenches. The latest antique building appears to be the circular structure and its late reparation affected the street by partially removing some slabs.

The geophysical scans from 2013 seem to indicate that the wall structures identified during this campaign could be some annexes of an earlier larger building (situated to the east) and that they could have been placed on top of a street, as we can see in the case of the West Gate excavation ${ }^{23}$. For now, we can only state that the probable street might overlap previously built constructions that seem to follow a regular urban system. In this manner, it will be possible to document the Hellenistic/Roman urban network, with a very probable change in the Late Antique/Early Byzantine period (Fig. 6-8).

The importance of this year's campaign consists in bringing to light new information concerning the urbanistic development of Limyra in the Late Antique period, together with a very detailed documentation of the stratigraphy correlated with the structures revealed and associated finds.

For the next campaign it is planned to continue and to extend the excavation and the documentation in this sector in order to obtain the maximum amount of information concerning urbanistic development from the Hellenistic until the Late Antique periods, together with find analyses that could provide ideas regarding functionalities.

\section{LATE CLASSICAL - EARLY HELLENISTIC POTTERY}

(K. Kugler)

During the 2016 campaign, the processing of older excavation material was started, because within the scope of the excavation campaign no Hellenistic layers had been reached.

At first, the material from the former excavation at the West Gate, which took place in 2011 and 2012 under the responsibility of U. Schuh, was reviewed. In total, the find numbers 064 to 144 were examined and approx. 320 diagnostic pieces were selected for further investigations. These shards were all drawn, photographed and analysed. Initial studies show that the material differs merely in some points from the West City material of the excavations of 2002-2004, which was examined by J. Gebauer in 2003-2005. The so-called "Streifen-und Wellenbandkeramik", which is mainly dated to the $6^{\text {th }}$ and $5^{\text {th }}$ century B.C., but nevertheless in some cases can extend to the $4^{\text {th }}$ century B.C. in the Lycian area, constitutes a large proportion within the West Gate material. (Fig. 18) Characteristics of this class are the bright clay as well as a bright slip, and the dark painting in the form of broad stripes and waves. The colour of the painting ranges between dark brown, dark reddish-grey and dark reddishbrown. Mostly, it shows a matte surface and is single-coloured. In some cases, the painting becomes glossy or even metallic glossy. Within this material, there is only one single shard with bichrome painting; the remaining "Streifen-und Wellenbandkeramik" is solely monochrome. Until now, conclusions regarding the spectrum of forms are difficult; never- 


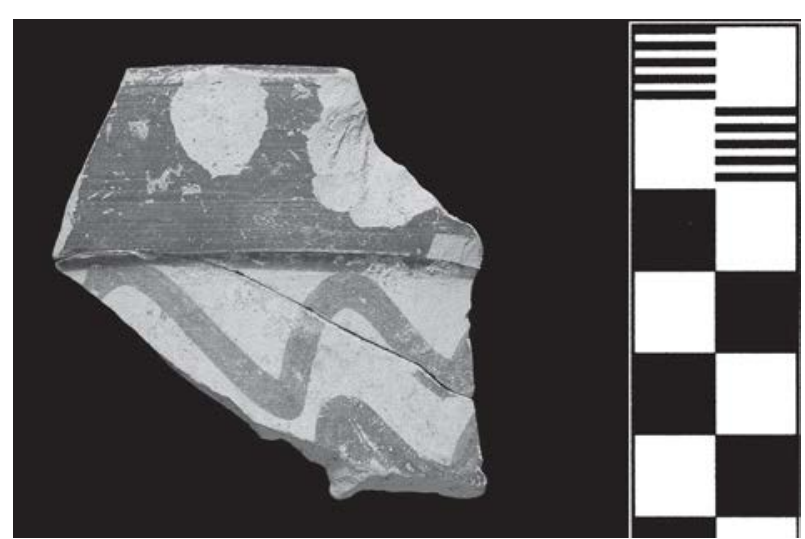

Fig. 18 : West Gate excavation, "Streifen- und Wellenbandkeramik" (Photo: R. Hügli).

theless, it appears that it broadly coincides with the spectrum of the western city excavation. Among this large volume of material, only a few red-figured fragments appeared. This is one of the differences in comparison to the West City excavation; another one is the absence of black-figured fragments. The black-glazed-ware clearly constitutes the largest proportion besides the "Streifen-und Wellenbandkeramik". Initial studies show that we are dealing with the typical and well-known forms of this ware (Fig. 19). The painting of this black glaze varies between deep, thick black through greenish black to sloppily applied glaze. Within this ware only a few fragments show decoration and when they do, mostly so-called "Strahlenbänder" and ovuli can be observed. One single shard with a stamped palmette can be recognized. Black-on-Red-Ware is missing completely, which is also a big difference in comparison to the western city excavation. In contrast, the lack of typical Hellenistic relief ware is consistent with the western city material.

Additionally, the ceramics from the excavations around the Xñtabura-sarcophagus were examined and approx. 80 selected pieces were chosen for further studies. Despite some difficulties with the reconstruction of the provenance due to missing information from the actual excavation work in the $1970 / 80$ s, it is a very interesting complex of finds. Within this spectrum, the black-glazed-ware clearly dominates, and preliminary studies show that it also includes the typical and well-known shapes of this ware. There are some sporadic shards with dark reddish-brown or dark grey slip and a few shards
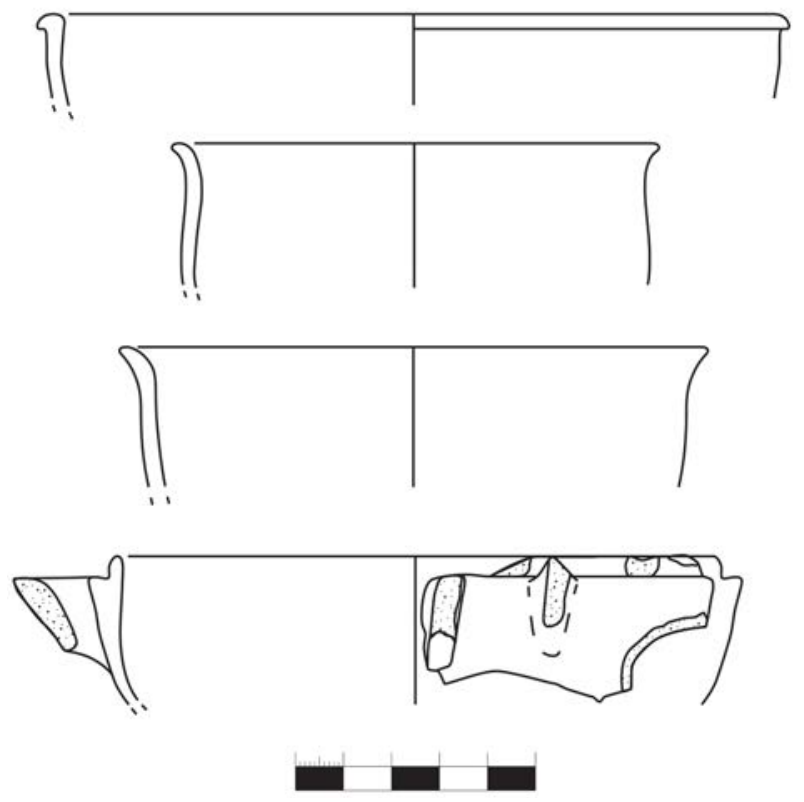

Fig. 19 : West Gate excavation, black-glazedware, dated to the $5^{\text {th }}$ and $4^{\text {th }}$ century B.C. (Drawings: K. Kugler).

can be assigned to the eastern Sigillata. Finally, only two shards of Hellenistic relief ware appear in this find complex. Hellenistic relief ware obviously did not play a significant role in Limyra because it appears only in small numbers, or not at all, in the various find complexes. This is an aspect that needs to be explored in further investigations.

Beside this work, the ceramic from the drilling cores was examined. These fragments were sighted, counted and first investigations were made.

\section{GEOARCHAEOLOGICAL RESEARCH IN LIMYRA}

(F. Stock and H. Brückner)

\section{Introduction}

Geoarchaeology is an interdisciplinary science at the interface between Natural Sciences (e.g. geology, geomorphology, geophysics, biology, hydrology, climatology) and Social Sciences (e.g. archaeology, human geography, history) ${ }^{24}$. It focuses on the reconstruction of ancient landscapes and on human-environment interactions ${ }^{25}$. Until the 1990s, only scattered joint projects involved the collaboration between Natural Sciences and Humanities ${ }^{26}$. Geoar- 


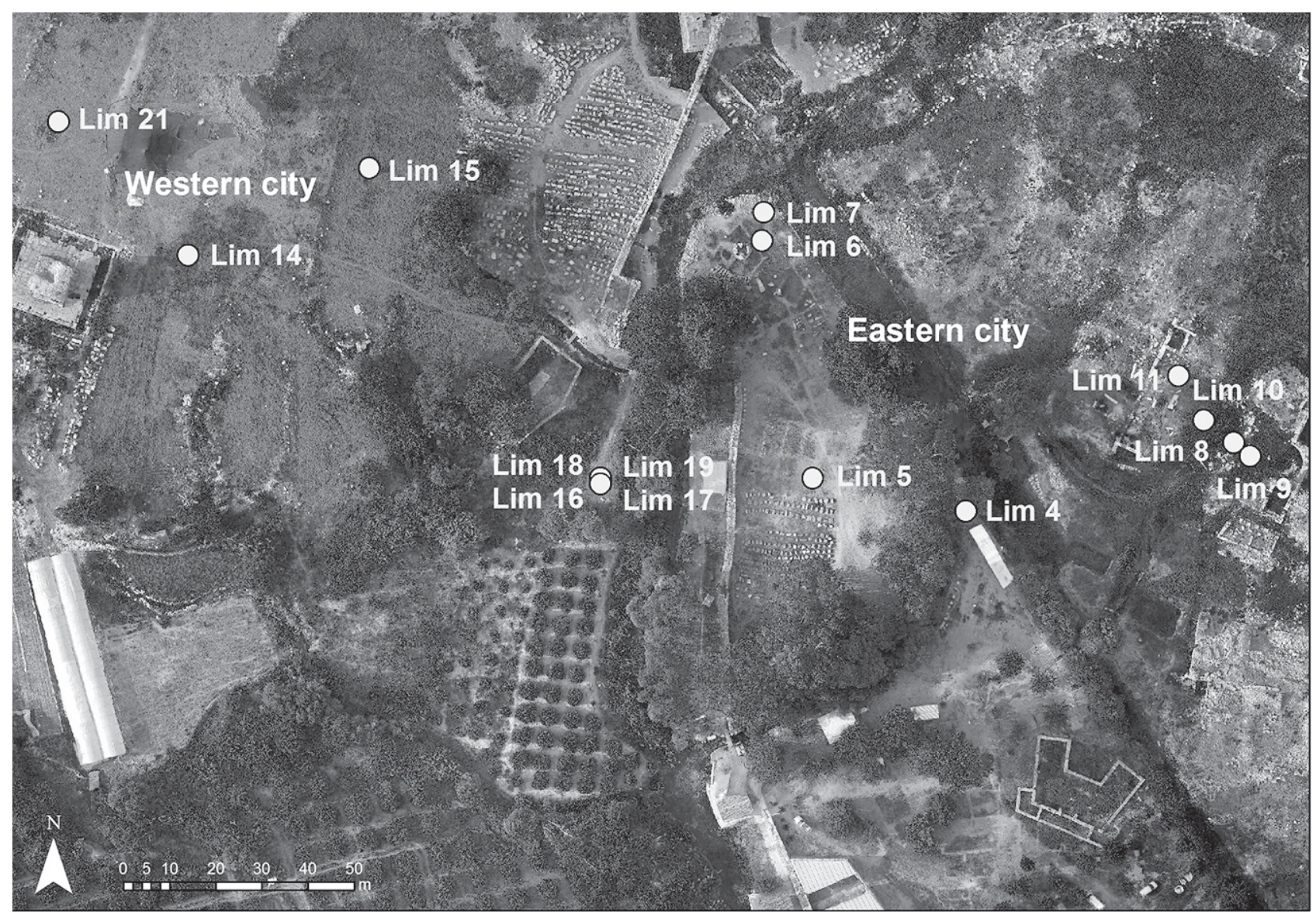

Fig. 20 : Location of drill cores in the city of Limyra (Satellite photo: ÖAI. Edited by H. Brückner).

chaeologists have since intensively investigated Holocene environments surrounding ancient settlements in order to document natural and humaninduced environmental changes. In Turkey, geoarchaeological studies have been conducted in the environs of ancient cities such as Troia (Troy) ${ }^{27}$, Mile$\operatorname{tos}^{28}$, in the environs of Pergamon ${ }^{29}$, Ephesos ${ }^{30}$, and on settlement sites such as Barcın Höyük ${ }^{31}$, Ilıpınar mound $^{32}$, Çukuriçi Höyük ${ }^{33}$ and Kinet Höyük ${ }^{34}$.

For Limyra and the Finike plain, E. Öner ${ }^{35}$ had contributed very valuable preliminary results on the evolution of the landscape. However, since these cores have neither been studied with geochemical and sedimentological analyses nor radiocarbon (AMS- ${ }^{14} \mathrm{C}$ ) dated, an intensive geoarchaeological research project was started in 2015 in the framework of a cooperation between the Austrian Archaeological Institute (ÖAI) and the University of Cologne ${ }^{36}$. Its main aims are to reconstruct (i) the environment, especially during the Classical to Late Roman periods; (ii) the geohydrological situation; (iii) the thickness of the settlement layers; (iv) the maximum extension of the former lake; to reveal (vi) the earthquake chronology and (vii) the spatio-temporal shifts

27) Kraft et al. 2003.

28) Brückner et al. 2006, 2014.

29) Schneider et al. 2014.

30) Brückner 2005; Brückner et al. 2008; Kraft et al. 2000, 2001, 2005, 2007; Stock et al. 2013, 2014, 2016.

31) Groenhuijzen et al. 2015.

32) Kayan 1995.

33) Stock et al. 2015.

34) Beach and Luzzader-Beach 2008.

35) Öner 2013.

36) Brückner et al. 2016. 
in the coastline. The geoarchaeological research design is according to $\mathrm{H}$. Brückner ${ }^{37}$ and $\mathrm{H}$. Brückner and R. Gerlach $(2011)^{38}$.

Sediment coring provides a complete high-resolution stratigraphy of the sediment archive ${ }^{39}$. The chronostratigraphy is generally well constrained, using a combination of three methods: (a) archaeological dating (e.g. diagnostic pottery), (b) radiocarbon (AMS- ${ }^{14} \mathrm{C}$ ) dating, and (iii) optically stimulated luminescence (OSL) dating. A suite of analytical techniques is applied to extract information about paleo-environmental changes (e.g. grain size, mineralogy, geochemistry, macro- and microfauna).

\section{Study area}

Limyra is located at the foothills of the Taurus Mountains. To the west, it is bordered by the BurdurFethiye Fault Zone ${ }^{40}$. Thus, earthquakes are quite common and already known since antiquity ${ }^{41}$. Several karstic springs occur in the direct environs of the city. Therefore, a considerable amount of water permanently flows through the ruins. Especially in the eastern part of the city, the groundwater level is high.

\section{Results}

As yet, 21 sediment cores (Lim 1 - Lim 21) have been retrieved from Limyra's city centre and its environs (Fig. 20). First results show that the city had been built on top of former lake sediments. Coring Lim 4 reveals the typical stratigraphy in the city area, Lim 13 and 20 the stratigraphy outside the city.

Sediment core in the city area: Lim 4 (Fig. 21)

Lim 4 is located in the southwestern part of the east city (surface $4.32 \mathrm{~m}$ above sea level (a.s.1.); total depth $10 \mathrm{~m}$ ). The lowermost part of the core consists of homogeneous light greyish clay and silt void of macrofauna (10-6.70 m b.s.; below surface). These are sediments of a former lake. Three peat layers of maximum $60 \mathrm{~cm}$ are intercalated (so-called "floating peats"); they represent the onset of the siltation of the lake. The reactivated lake phases, expressed in the rapid transitions from peat to lake strata, may be explained by earthquakes with coseismic subsidence. G. Rantitsch ${ }^{42}$ already demonstrated with a palaeo-hydrogeological model that subsidence occurred at Toçak Dağı. In consequence, the groundwater table rose.

The overlying sediments consist of fluvial sands with a fining-upward sequence (gravel at the base, covered by sands and alluvia). They provide information about changing river channels. The uppermost $4 \mathrm{~m}$ are rich in cultural layers with ceramic shards, brick and bone fragments, charcoal, as well as corefilling layers of edged stones (esp. limestones). Obviously people started to settle when the river changed its channel. In order to date the first settlement layers, diagnostic ceramic fragments and ${ }^{14} \mathrm{C}$ age estimates are needed.

$\underline{\text { Sediment cores outside the ancient city ( } \operatorname{Lim} 13}$ and Lim 20) (Fig. 22)

Lim 13 (3.39 m a.s.1.; depth $10 \mathrm{~m}$ ) southeast of the ancient city and $50 \mathrm{~m}$ to the east of the river Limyros confirms the sediment layers of drill core $\operatorname{Lim} 4$. The base of the core shows sediments of the lake, followed by a fluvial facies (fining-upward sequence, sands, alluvium). Despite one ceramic sherd found at a depth of $3.40 \mathrm{~m}$ b.s. (probably transported by the river), anthropogenic layers are absent. It is highly probable that the lake originated from an initial lagoon. When the latter was closed, it quickly turned to fresh-water due to the continued strong inflow from the karstic springs at the foot of the Taurus Mountains. However, until now, no brackish or marine fossils have been found. For 2017, a deep drill core is planned in order to solve this question.

Seawards of Lim 13, E. Öner noted a structure which can be interpreted as beach barrier ${ }^{43}$. Lim 20 (0.41 m a.s.1.; depth $6 \mathrm{~m}$ ) was carried out in order to verify this assumption. On top of fluvial sediments follow homogeneous sands (contact at $5.34 \mathrm{~m}$ b.s.). The stratigraphy most likely represents the uppermost layers of a beach barrier which is overlain by dunes. Thus, the explanation that the origin of the lake was a lagoon is the most probable one. It must have been deep, since even in the deepest drill core ${ }^{44}$ no marine or brackish fossils were found.

\footnotetext{
37) Brückner 2011.

38) Brückner and Gerlach 2011.

39) Goiran and Morhange 2001.

40) Hall et al. 2014.

41) Akyüz and Altunel 2001; Karabacak et al. 2013

42) Rantitsch et al. 2016

43) Öner 2013.

44) see Öner 2013: down to $15 \mathrm{~m}$.
} 


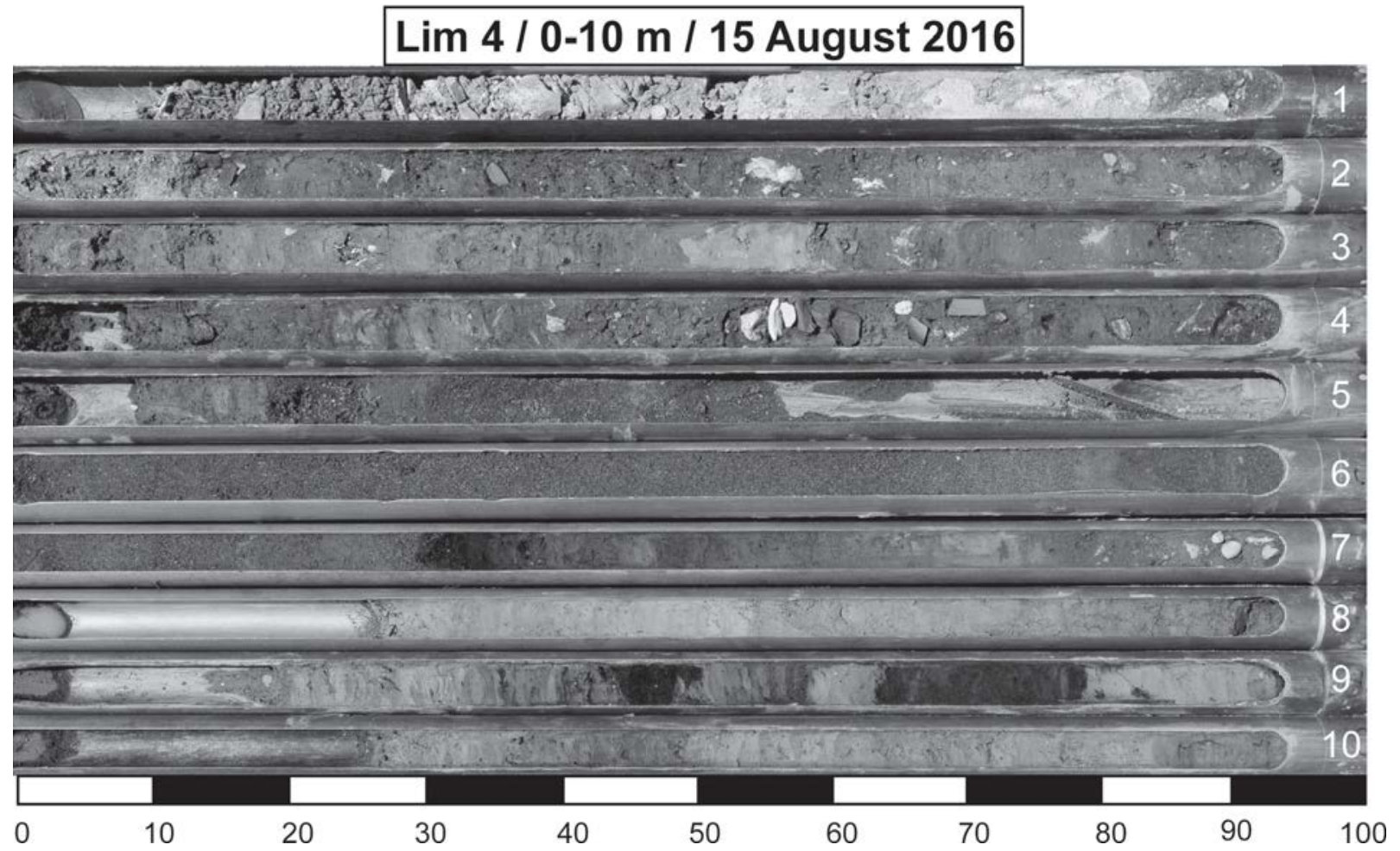

Fig. 21 : Drill core Lim 4 (Photo: H. Brückner).

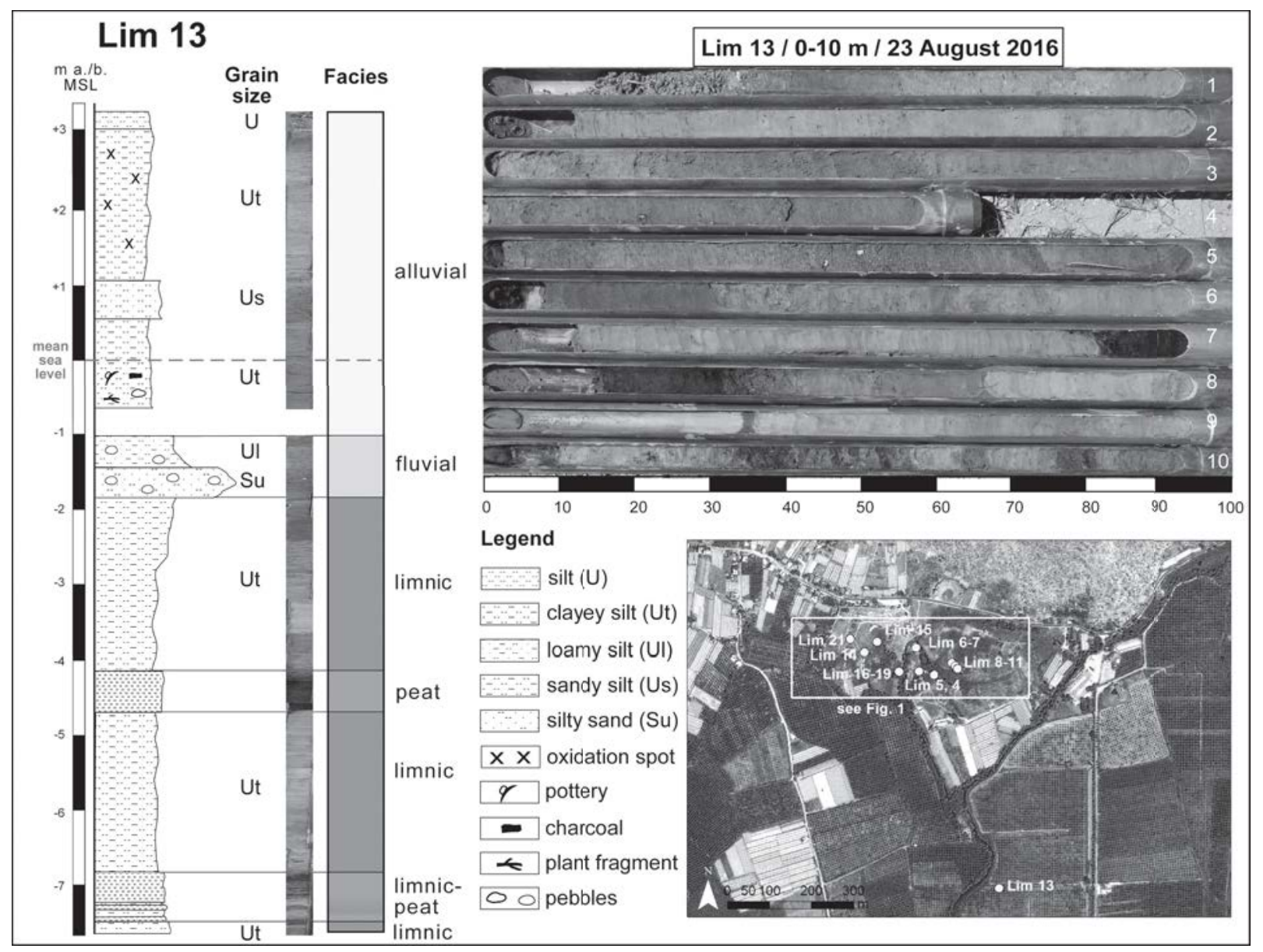

Fig. 22 : Drill core Lim 13 with facies interpretation. The core is located $c a 500 \mathrm{~m}$ south of the ancient city (Photo, plan, drawings: F. Stock). 


\section{Drill cores in the eastern city}

Five drill cores are located in the Episcopal Church; Lim 3, 8 and 9 in the north-eastern part and Lim 10 and 11 in its southwestern part (Fig. 2). The upper $2.20 \mathrm{~m}$ of Lim 11 are rich in artefacts (ceramics, marble, bricks, and glass) and stones. Below this layer, the swampy environment had been consolidated with a limestone pavement. The archaeological strata cover a former river channel which had been transformed into an oxbow lake. This may be attested by the graded bedding with fining-upward sequence. The river eroded lacustrine sediments, into which two peat layers are intercalated.

In order to better understand the shift of the river channels and the settlement history, Lim 4 was drilled to the north of the çardaks (i.e. the sleeping huts of the excavation's collaborators), and Lim 5, 6 and 7 on the so-called "Steingarteninsel". Lim 5 and 7 reached depths of 9-10 m, $\operatorname{Lim} 4 / 1,4 / 2$ and 6 only 1.40 to max. $3.40 \mathrm{~m}$ b.s. (drilling process was stopped due to massive limestone layers).

All sediment cores are dominated by lake sediments from the base to 5-6 $\mathrm{m}$ b.s. Peat layers are intercalated and represent the starting siltation process. Then follow fluvial sands with a fining-upward sequence (gravel at the base, overlain sands and alluvia). The strata provide information about shifting river channels. Anthropogenic layers form the top part of the core. Only Lim 7 is an exception: no fluvial sediments were detected and cultural layers start already at $4.72 \mathrm{~m}$ b.s.

Drill cores between the western and the eastern city

Drill cores Lim 12 and 16-19 between the eastern and the western city were of special interest for verifying (i) the hypothesis of a former river course in this area; (ii) the maximum extension of the former lake; and (iii) the earthquake chronology. Lim 12 shows at the base lake sediments with intercalated peat. Then follow sands (up to $5.60 \mathrm{~m} \mathrm{b.s.)}$. A sharp contact separates them from pebbles. They are overlain by peat with a thickness of $c a 25 \mathrm{~cm}$, limnic strata, fluvial layers with pebbles and a stone setting (2.95-2.88 m b.s.). The uppermost part of the drill core is dominated by cultural layers.

This sediment sequence, especially at a depth of 5-6 m, was also confirmed in Lim 16, Lim 17 and Lim 19 (Lim 18 only reached a depth of $3 \mathrm{~m}$, drilling was stopped due to a massive stone): lake sediments, large pebbles and edged stones as well as peat. The lakeshore always occurs at a depth of

\section{Cross section Hellenistic city}

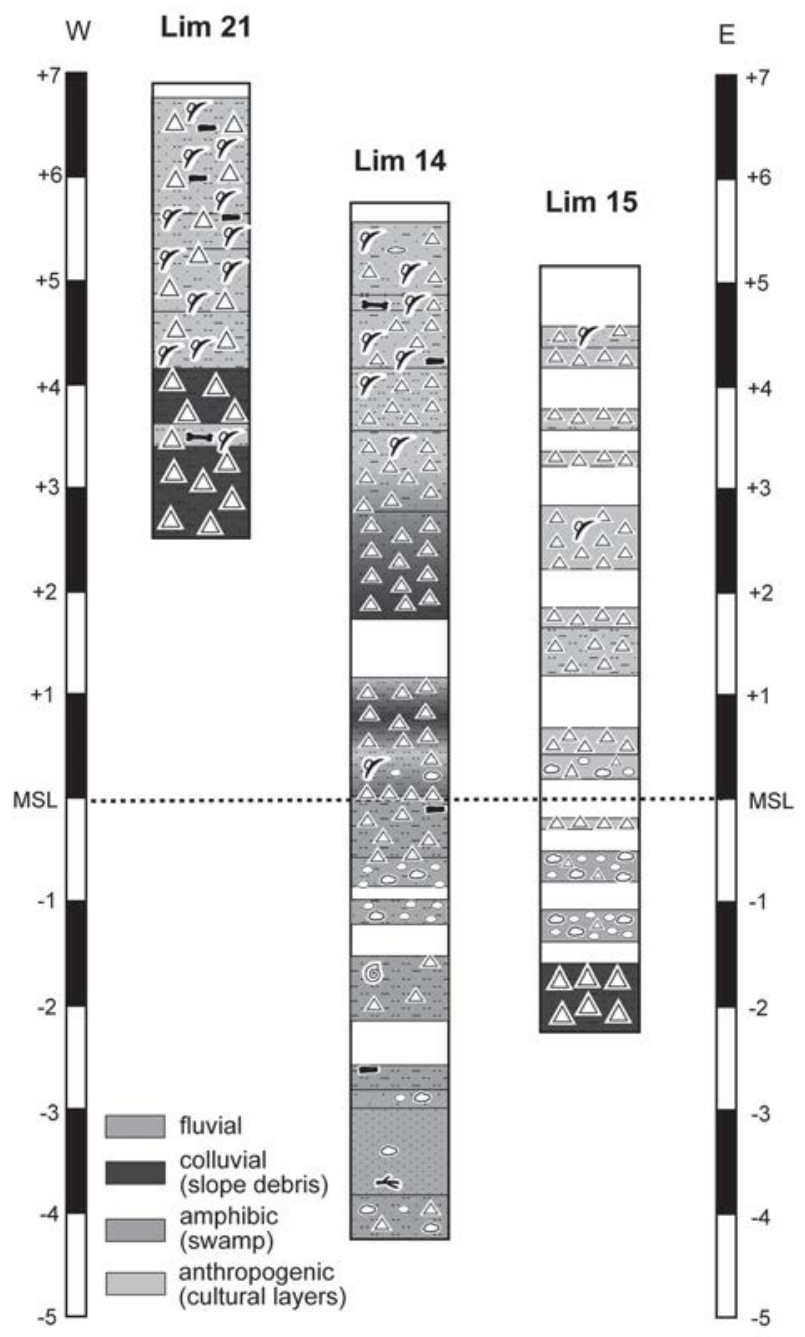

Fig. 23 : Cross section of the cores in the western city of Limyra (Cross section: F. Stock).

$5.60 \mathrm{~m}$ b.s. The stones seem to have been intentionally deposited. It seems that people settled at the lake shore. The peat layer on top may represent the changing hydrology and co-seismic subsidence. The fluvial sediments support the assumption of a former river course. The uppermost $3 \mathrm{~m}$ are cultural layers.

Drill cores in the western city (Fig. 23)

Lim 21 was drilled in the Hellenistic city. Pleistocene slope debris occurs from 4.40 to $2.77 \mathrm{~m}$ b.s. Then follows a transition zone $(2.77-2.70 \mathrm{~m} \mathrm{~b}$.s. $)$, and cultural layers follow up to the surface. They reveal that people settled directly on top of the slope debris. 
Lim 15 (max. depth $7.45 \mathrm{~m}$ b.s.), located close to a wall, is dominated by limestones. The transition to the slope debris was not clearly visible. The base of Lim 14 is characterised by fluvial and limnic/swampy sediments. With a sharp contact, cultural layers start at $5.73 \mathrm{~m}$ b.s. In this part of the city sediments of the palaeo-lake were not encountered. Obviously, the former lake shores were more seawards.

M.S. et al.

\section{REFERENCES}

Akyüz, S.H.and Altunel, E., 2001: "Geological and archaeological evidence for post-Roman earthquake surface faulting at Cibyra, SW Turkey", Geodinamica Acta 14: 95-101.

Barnea, Al., 1979: "Sectorul A și via principalis B-C", in Barnea, I., Tropaeum Traiani, I, Cetatea, București: 79-93.

Beach, T.P. and Luzzader-Beach, S., 2008: "Geoarchaeology and aggradation around Kinet Höyük, an archaeological mound in the Eastern Mediterranean, Turkey", Geomorphology 101: 416-428.

Bes, P., 2015: "Late Antique/Early Byzantine Pottery from the East and West Gates", in Seyer, M., "Limyra 2014," News of Archaeology from Anatolia's Mediterranean Areas 13: 72-81.

Brückner, H., 2005: "Holocene shoreline displacements and their consequences for human societies: the example of Ephesus in Western Turkey", Zeitschrift f. Geomorphologie N. F., Suppl.-Vol. 137: 11-22.

- 2011: "Geoarchäologie - in Forschung und Lehre", in Bork, H.-R., Meller, H. and Gerlach, R. (eds.), Umweltarchäologie - Naturkatastrophen und Umweltwandel im archäologischen Befund, 3. Mitteldeutscher Archäologentag vom 07. bis 09. Oktober 2010 in Halle (Saale). - Tagungen des Landesmuseums für Vorgeschichte, Halle (Saale): 6: 9-20.

Brückner, H., Müllenhoff, M., Gehrels, R., Herda, A., Knipping, M. and Vött, A., 2006: "From archipelago to floodplain - geographical and ecological changes in Miletus and its environs during the past six millennia (Western Anatolia, Turkey)", Zeitschrift f. Geomorphologie N. F., Suppl.-Vol. 142: 63-83.

Brückner, H., Kraft, J.C. and Kayan, İ., 2008: "'Vom Meer umspült, vom Fluss begraben -zur Paläogeographie des Artemisions", in Muss, U. (ed.), Die Archäologie der ephesischen Artemis. Gestalt und Ritual eines Heiligtums. Phoibos, Wien: 21-31.

Brückner, H. and Gerlach, R., 2011: "Geoarchäologie - von der Vergangenheit in die Zukunft", in Gebhardt, H., Glaser, R., Radtke, U. and Reuber, P. (eds.), Geographie - Physische Geographie und Humangeographie, Heidelberg: 1179-1186.

Brückner, H., Herda, A., Müllenhoff, M., Rabbel, W., Stümpel, H., 2014: "On the Lion Harbour and other harbours in Miletos: recent historical, archaeological, sedimentological, and geophysical research", Proceedings of the Danish Institute at Athens, Vol. VII, Aarhus: 49-103.

Brückner, H., Stock, F. and Uncu, L., 2016: "Palaeogeographical Research", ANMED Anadolu Akdenizi Arke- oloji Haberleri. News of Archaeology from Anatolia's Mediterranean Areas 2016-14: 81-82.

Cavalier, L., 2012: "Deux nouveaux temples à Limyra?", in Seyer, M. (ed.), 40 Jahre Grabung Limyra, Akten des internationalen Symposions Wien, 3.-5. Dezember 2009, Vienna: 133-139.

Dinstl, A., 1993: "Ein Bukranienfries aus Limyra", in Borchhardt, J. and Dobesch, G. (eds.), Akten des II. Internationalen Lykien-Symposions 2, Wien, 6.-12. Mai 1990, [18. Ergänzungsband TAM], Vienna: 161-167.

Gămureac, E., 2010: "Piese de arhitectură şi sculpturale descoperite în sectorul B de la Tropaeum Traiani (Architecture and Sculpture Pieces Discovered in Tropaeum Traiani Sector B)", Pontica XLIII, Constanța: 203-19.

Goiran, J.-P. and Morhange, C., 2001: "Geoarcheology of ancient mediterranean harbours", Topoi 11 (2): 647669.

Groenhuijzen, M.R., Kluiving, S.J., Gerritsen, F.A. and Künzel, M., 2015: "Geoarchaeological research at Barcın Höyük: Implications for the initial Neolithic occupation of northwest Anatolia", Quaternary International 367: 51-61.

Hall, J., Aksu, A.E., Elitez, I., Yaltırak, C. and Çifçi, G., 2014: "The Fethiye-Burdur Fault Zone: A component of upper plate extension of the subduction transform edge propagator fault linking Hellenic and Cyprus Arcs, Eastern Mediterranean", Tectonophysics 635: 80-99.

Karabacak, V., Yönlü, Ö., Dökü, E., Kıyak, N.G., Altunel, E., Özüdoğru, Ş., Yalçıner, C.C., Akyüz, H.S., 2013: "Analyses of seismic deformation at the Kibyra Roman stadium, Southwest Turkey", Geoarchaeology 28: 531-543.

Kayan, I., 1995 : "The geomorphological environment of the Ilipinar mound", in Roodenberg, J. (ed.), The Ilipinar excavations I. Five seasons of fieldwork in NW Anatolia, Nederlands historisch-archaeologisch Institut, Istanbul: 17-34.

Konecny, A. and Marksteiner, T., 2007: 'Zur Bebauungsgeschichte des Areals hinter der klassischen Stadtmauer: Ein Vorbericht", in Seyer, M. (ed.), Studien in Lykien, [8. Ergänzungsheft JÖAI], Vienna: 15-28.

Kraft, J.C., Kayan, İ., Brückner, H. and Rapp, G., 2000: "A geological analysis of ancient landscapes and the harbors of Ephesus and the Artemision in Anatolia", Jahreshefte des Österreichischen Archäologischen Institutes 69: 175-232.

Kraft, J.C., Kayan, İ. and Brückner, H., 2001: “The geological and paleogeographical environs of the Artemision", in Muss, U. (ed.), "Der Kosmos der Artemis von 
Ephesos", Österreichisches Archäologisches Institut, Sonderschriften 37, Wien: 123-133.

Kraft, J.C., Kayan, İ., Brückner, H. and Rapp, G., 2003: "Sedimentary facies patterns and the interpretation of paleogeographies of ancient Troia", in Wagner, G.A., Pernicka, E. and Uerpmann, H.P. (eds.), Troia and the Troad. Scientific approaches, Springer Series: Natural Science in Archaeology. Berlin, Heidelberg, New York: 361-377.

Kraft, J.C., Brückner, H. and Kayan, İ., 2005: "'The sea under the city of ancient Ephesos", in Brandt, B., Gassner, V. and Ladstätter, S. (eds.), Synergia. Festschrift F. Krinzinger, Bd. 1, (Phoibos Verlag), Wien: 147-156.

Kraft, J.C., Brückner, H., Kayan, İ. and Engelmann, H., 2007: "The geographies of ancient Ephesus and the Artemision in Anatolia", Geoarchaeology 22 (1): 121149.

Kugler, K., in press: "'Late Classic/Early Hellenistic Pottery", in Seyer, M., "Limyra 2016”, News of Archaeology from Anatolia's Mediterranean Areas 15, 2017.

Marksteiner, T., 1997: Die befestigte Siedlung von Limyra. Studien zur vorrömischen Wehrarchitektur und Siedlungsentwicklung in Lykien unter besonderer Berücksichtigung der klassischen Periode, [Forschungen in Limyra 1] Vienna.

Marksteiner, T., Lemaître, S. and Yener-Marksteiner, B., 2007: "Die Grabungen am Südtor von Limyra: Die Grabungen der Jahre 1982-1986 am Südtor von Limyra, Vaisselle antique à Limyra en Lycie orientale (sondages 3A et 3B), Keramik aus der Sondage 5 in der Weststadt von Limyra", Jahreshefte des Österreichischen Archäologischen Instituts, 76: 171-277.

Marksteiner, T., 2012: "Die Siedlungsgeschichte der ostlykischen Polis Limyra: Ein wissenschaftlicher Essay", in Seyer, M. (ed.), 40 Jahre Grabung Limyra. Akten des internationalen Symposions Wien, 3.-5. Dezember 2009, [Forschungen in Limyra 6], Vienna: 199-210.

Marriner, N., Morhange, C. and Goiran, J.P., 2010: "Coastal and ancient harbour geoarchaeology", Geology Today 26: 21-27.

Öner, E., 2013: Likya'da Paleocoğrafya ve Jeoarkeoloji Araştırmaları, Ege Üniversitesi Yayınları, Edebiyat fakültesi Yayın No: 182, İzmir.

Panaite, A., Pană, C., Bucurei, A., Cerveanu, I. and Dragostin, M., 2010: "Adamclisi, com. Adamclisi, jud. Constanța, Sector A - la N de Basilica A", Cronica Cercetărilor Arheologice, Campania 2009, București: 13-14.

Rantitsch, G., Prochaska, W., Seyer, M., Lotz, H. and Kurtze, C., 2016: " The drowning of ancient Limyra (southwestern Turkey) by rising groundwater during Late Antiquity to Byzantine Times", Austrian Journal of Earth Sciences 109, 2: 203-210.

Rapp, G. and Hill, C.L., 2006: Geoarchaeology: the Earth-Science Approach to Archaeological Interpretation, Yale University Press, New Haven.

Schneider, S., Matthaei, A., Bebermeier, W. and Schütt, B., 2014: "'Late Holocene human-environmental interactions in the Eastern Mediterranean: Settlement history and paleogeography of an ancient Aegean hilltop settlement", Quaternary International 324: 84-98.

Seyer, M., 1991/92: "Die Wohnsiedlung auf den Hangterrassen in Limyra", in J. Borchhardt und Mitarbeiter, "Grabungen und Forschungen in Limyra aus den Jahren 1984-1990", Jahreshefte des österreichischen archäologischen Instituts (JÖAI) 61, 1991/92 Beiblatt: 141-145.

- 1993: "Die Grabung in den Hanghäusern von Limyra", in Borchhardt, J. and Dobesch, G. (eds.), Akten des II. Internationalen Lykien-Symposions 2, Wien, 6.-12. Mai 1990, [18. Ergänzungsband TAM], Vienna: 171181.

- 1997 : "Die Grabung in der NW-Stadt", in J. Borchhardt und Mitarbeiter, "Grabungen und Forschungen in Limyra aus den Jahren 1991-1996", Jahreshefte des Österreichischen Archäologischen Instituts (JÖAI) 66, 1997 Beiblatt: 338-348.

Seyer, M. and Schuh, U., 2012: "Excavation in the West City", in Seyer, M., "Limyra 2011", News of Archaeology from Anatolia's Mediterranean Areas 10: 5964.

Seyer, M., 2013: "Urbanistische Forschungen in Limyra (Lykien)", Archäologie Österreichs 24, 1, 2013 : 55-63.

- 2014: "Limyra 2013", News of Archaeology from Anatolia's Mediterranean Areas 12: 73-80.

Seyer, M. and Schuh, U., 2013a: "West Gate Excavation", in Seyer, M., "Limyra 2012", News of Archaeology from Anatolia's Mediterranean Areas 11: 83-89.

-2013: "Grabung in der Weststadt", in M. Seyer und Mitarbeiter, "Limyra 2012", Kazı Sonuçları Toplantısı (KST) 35, 1: 406-408.

Seyer, M., in press: "'Geopysikalische Untersuchungen in Limyra", in Dündar, E., Aktaş, Ş., Koçak, M. and Erkoç, S. (eds.), Lykiarkhissa, Festschrift für Havva İşkan (in press).

Stanzl, G., 2012: "Zur Neuaufnahme der Arbeiten am Ptolemaion in Limyra", in Seyer, M. (ed.), 40 Jahre Grabung Limyra, Akten des internationalen Symposions, Wien, 3.-5. Dezember 2009, [Forschungen in Limyra 6] Vienna: 327-342.

- 2016: "'Werkspuren und Bautechnik am Ptolemaion von Limyra. Eine ostlykische „Bauhütte“ im Dienst der Ptolemäer?", in Kurapkat, D. and Wulf-Rheidt, U. (eds.), Werkspuren. Materialverarbeitung und handwerkliches Wissen im antiken Bauwesen. Internationales Kolloquium, Berlin, 13.-16. Mai 2015, Deutsches Archäologisches Institut, Architekturreferat, Disk AB 12, Regensburg: 209226.

Stock, F., Pint, A., Horejs, B., Ladstätter, S. and Brückner, H., 2013: "In search of the harbours: New evidence of Late Roman and Byzantine harbours of Ephesus", Quaternary International 312: 57-69.

Stock, F., Kerschner, M., Kraft, J. C., Pint, A., Frenzel, P. and Brückner, H., 2014: "The palaeo-geographies of Ephesos (Turkey), its harbours, and the Artemision - a gearchaeological reconstruction for the timespan 1500300 BC", Zeitschrift f. Geomorphologie N. F., Suppl.Vol. 58 (2): 33-66. 
Stock, F., Ehlers, L., Horejs, B., Knipping, M., Ladstätter, S., Seren, S. and Brückner, H., 2015: "Neolithic settlement sites in Western Turkey - palaeogeographic studies at Çukuriçi Höyük and Arvalya Höyük", Journal of Archaeological Science: Reports 4: 565-577.

Stock, F., Knipping, M., Pint, A., Ladstätter, S., Delile, H., Heiss, A.G., Laermanns, H., Mitchell, P., Ployer, R., Steskal, M., Thanheiser, U., Urz, R., Wennrich, V. and Brückner, H., 2016: "'Human impact on Holocene sediment dynamics in the Eastern Mediterranean - the example of the Roman harbour of Ephesus", Earth Surface Processes and Landforms 41: 980-996.

Vroom, J., 2004: "'Late antique pottery, settlement and trade in the East Mediterranean. A preliminary comparison of ceramics from Limyra (Lycia) and Boeotia", in Bowden, W., Lavan, L. and Machado, C. (eds.), Recent research on the late antique countryside, Leiden: 281-330.

- 2005: "New light on 'Dark Age' pottery: A note on finds from south-western Turkey", Rei Cretariae Romanae Factorum Acta 39: 249-254.
Wörrle, M., 1977: "Epigraphische Forschungen zur Geschichte Lykiens I. Ptolemaios I. und Limyra", Chiron 7: 43-66.

- 2010: "Epigraphische Forschungen zur Geschichte Lykiens VIII. Ein ptolemäisches Prostagma aus Limyra über Missstände beim Steuereinzug", Chiron 40: 359396.

-2011: "Epigraphische Forschungen zur Geschichte Lykiens X. Limyra in seleukidischer Hand", Chiron 41: 377-412.

- 2012: “Anfang und Ende von Limyras ptolemäischer Zeit", in Seyer, M. (ed.), 40 Jahre Grabung Limyra, Akten des internationalen Symposions Wien, 3.-5. Dezember 2009, [Forschungen in Limyra 6], Vienna: 359-369.

- 2015: "Die ptolemäische Garnison auf der Burg von Limyra im Licht einer neuen Inschrift", in BeckBrandt, B., Ladstätter, S. and Yener-Marksteiner, B. (eds.), Turm und Tor, Gedenkkolloquium für T. Marksteiner, Wien, 9.-10. November 2012, [Forschungen in Limyra 7], Vienna: 291-304. 